Buca Eğitim Fakültesi Dergisi, 2021, say1 52, s. 622-647

Araştırma Makalesi
The Journal of Buca Faculty of

Education, 2021, issue 52, p. 622-647

Research Article

\title{
Uzaktan Eğitim Hakkında Öğretmen Görüşleri
}

\section{Teachers' Opinions Related to Distance Education}

\author{
Gökhan TAŞKIN ${ }^{1}$, Gökhan AKSOY ${ }^{2}$
}

\author{
${ }^{I}$ Sorumlu Yazar, Doktora Öğrencisi, Matematik ve Fen Bilimleri Eğitimi Bölümü, Eğitim \\ Bilimleri Enstitüsü, İnönü Üniversitesi, Türkiye, gkhntskn4288@gmail.com, \\ (https://orcid.org/0000-0003-1858-7084) \\ ${ }^{2}$ Prof. Dr., Matematik ve Fen Bilimleri Eğitimi Bölümü, Eğitim Fakültesi, İn̈nü Üniversitesi, \\ Türkiye, aksoygok44@gmail.com, (https://orcid.org/0000-0002-2822-9419)
}

Geliș Tarihi: 12.07.2021

Kabul Tarihi: 27.12 .2021

\section{ÖZ}

$\mathrm{Bu}$ çalışmanın amacı uzaktan eğitime ilişkin öğretmen görüşlerini objektif bir şekilde ortaya koymaktır. Araştırmada karma yöntem araştırma modeli olan yakınsayan paralel desen kullanılmıştır. Araştırma 2020-2021 eğitim öğretim yılı ikinci döneminde gerçekleştirilmiştir. Çalışmanın nicel katılımcı grubu durum örneklemesi yoluyla belirlenmiştir. Araştırma Konya ilinde görev yapan 292 öğretmen ile gerçekleştirilmiştir. Nitel katılımcı grubu ise maksimum çeşitlilik örnekleme yöntemiyle belirlenmiştir. $\mathrm{Bu}$ kapsamda 8 öğretmen ile görüşme gerçekleştirilmiştir. Araştırmanın nicel bölümünde katılımcılara ' 'Uzaktan Eğitime İlişkin Görüş Anketi' uygulanmıştır. Araştırmanın nitel bölümünde öğretmenlerle uzaktan eğitim hakkında öğretmen görüşleri yarı yapılandırılmış görüşme formu ile görüşmeler gerçekleştirilmiştir. Nicel verilerin analizinde betimsel istatistikler, parametrik olmayan testler kullanılmıştır. Nitel verilerin analizi için içerik analizi kullanılmıştır. Elde edilen bulgulara göre öğretmenler uzaktan eğitimde firsat eşitliğinin sağlanması için tüm öğrencilerin teknolojik alt yapıya sahip olması gerektiği görüşündedirler. Ayrıca öğretmenler uzaktan eğitimin öğrencilere fiziksel, psikolojik ve sosyalleşme bakımdan zarar verdiği görüşündedir. Çalışma sonucunda Milli Eğitim Bakanlığı (MEB)'nın uzaktan eğitimi sağlıklı bir şekilde yürütebilmesi için gerekli materyalleri sağlaması önerilmektedir.

Anahtar Kelimeler: Uzaktan eğitim, öğretmen görüşleri, karma yöntem.

\begin{abstract}
The aim of this study is to reveal the opinions of teachers about distance education in an objective way. Convergent parallel design, which is a mixed method research model, was used in the research. The study was researched in the second semester of the 2020-2021 academic year. The quantitative participant group of the study was determined through case sampling. The group of the research consists of with 292 teachers working in Konya province. The qualitative participant group of the study was determined through the maximum variation sampling method. In this contex̄t, interview was carried out with 8 teachers. In the quantitative part of the research, the "Opinion Questionnaire on Distance Education" was conducted to the participants. In the qualitative part of the study, interviews were conducted with teachers through a semi-structured interview form about distance education. Descriptive statistics, non-parametric tests were used in the analysis of quantitative data. Content analysis was used for the analysis of qualitative data. According to the results obtained, teachers are of the opinion that all students should have a technological infrastructure in order to ensure equality of opportunity in distance education. In addition, teachers are of the opinion that distance education harms students in terms of physical, psychological and socialization. As a result of the study, it is recommended that the Ministry of National Education (MoNE) provide the necessary materials to conduct distance education in a healthy way.
\end{abstract}

Keywords: Distance education, teacher opinions, mixed method. 


\section{GIRIŞ}

Son yıllarda yaşanan gelişmeler, olaylar ve durumlar bilimsel ve teknolojik faaliyetleri etkilerken insanlığın yaşam tarzını da etkilemektedir. Nitekim 2019 yılının başlarında ortaya çıkan COVID-19 (Koronavirüs) salgını insanların yaşam şekillerini etkilediği gibi tüm alanlarda birtakım müdahalelere ve uygulamalara neden olmuştur. COVID-19 salgını sağlık, ekonomi, sosyoloji vb. alanları etkilediği gibi eğitim alanını da etkilemiştir. Pandemi sürecinde eğitim alanında ön plana çıkan uzaktan eğitim bu uygulamaların başını çekmektedir. Uzaktan eğitim, eğitim bilimleri alanında yaygın olarak kullanılmamaktaydı ancak uygulama örnekleri bazı üniversitelerde zorunlu dersler, seminerler ve konferanslar gibi birtakım faaliyetlerle sınırlı kalmaktaydı. Ancak yaşanılan salgın süreciyle birlikte uzaktan eğitim, eğitimin tüm kademelerinde yerini almıştır. Ancak uzaktan eğitim uygulamalarında öğretmenlerin ve öğrencilerin uzaktan eğitim için hazırbulunuşluklarının olmadığı, uzaktan eğitim alt yapı imkânsızlığı gibi sıkıntılar doğurmuştur (Burke ve Dempsey, 2020).

Uzaktan eğitim, eğitim öğretim sürecinin kitle iletişim araçları (bilgisayar, tablet, telefon ve televizyon) yoluyla sürdürüldüğü bir yöntemdir (Cab1 ve Ersoy, 2017). Nitekim toplumun hızlı bir şekilde kabullendiği online teknolojiler sayesinde toplumun kültürel değerleri etkilenmekte ve değişmektedir (Bayrak, Aydemir ve Karaman, 2017). Valentine (2002) uzaktan eğitimi öğrencilerin ve öğretmenlerin zaman ve mekân bakımından farklı yerlerde olmalarından kaynaklı, öğrenmenin kolaylaştırılması ve derslerin yapılması için bilgi teknolojilerini aktif bir şekilde kullanmasına dayalı öğretim yöntemi olarak tanımlanmaktadır. $\mathrm{Bu}$ tanıma ilaveten ders içeriğine uygun materyal ve dokümanların sıklıkla kullanıldı̆̆ 1 ve daha bağımsız olarak yürütülen bir eğitim şekli olarakta tanımlanmaktadır (Uşun, 2006). Yenal (2009) ise uzaktan eğitimi, bireylere kendi kendilerine öğrenme imkânını sağlayan, geleneksel eğitime göre daha esnek ve birey koşullarına uyarlanabilir olan bir eğitim olarak tanımlamıştır. Başka bir açıklamada yüz yüze eğitimin yetersiz kaldığı noktada teknolojik gelişmelere bağlı olarak uzaktan eğitim gündeme gelmiştir (Kışla, 2005). Yine uzaktan eğitim öğrencilerin öğrenme sorumluluklarının farkında olmaları, durumuna göre mekândan ve zamandan bağımsız bir şekilde öğretenler ile öğrenenler arasında teknoloji yardımıyla iletişim ve etkileşim kurulmasını sağlayan eğitim öğretim sürecidir (Özmen, 2010). Uzaktan eğitimle ilgili açıklamalar ve tanımlamalara bakıldığında zaman ve mekân yönünden bağımsız ortam, paydaşların okula gitme zorunluluğunun olmaması, teknoloji araçları ile derslerin işlenmesi, derslerin kayıt altına alınarak tekrar izlenmesi ve çağdaş yenilikçi bir eğitim yaklaşımı temaları ön plana çıkmaktadır.

Uzaktan gerçekleştirilen bir eğitimde çeşitli ögeler bulunmakta ve bu ögeler birbirleriyle etkileşim hâlindedirler (Garrison, 1993). Uzaktan eğitim öğelerinin öğrenen, öğreten ve içerik oluştuğu konusunda ortak bir görüş mevcuttur (Garrison, 1993; Moore, 1989). Bu öğelere ilaveten Keegan (1986) öğrenci destek hizmetleri ve eğitim materyalleri hazırlama organizasyonlarını eklemiştir. Yine yazılım geliştirme ve sunucu bakımı da ihtiyaç duyulan öğeler arasındadır. Uzaktan eğitimdeki ögelerin birbiri ile olan ilişkisine bakıldığında ise literatürde öğreten-öğrenen, öğrenen-öğrenen ve öğrenen-içerik öğeleri arasındaki etkileşimlerden bahsedilmektedir (Garrison, 1993; Moore, 1989). Bahsi geçen bu etkileşim türleri asgari düzeyde gerçekleştirilecek bir uzaktan eğitim faaliyeti için gerekli olan temel bileşenlerdir. Daha gelişmiş uzaktan eğitim uygulamalarında destek personeli, içerik hazırlama personeli, yazılım geliştiriciler, mühendisler ve kurum yöneticileri de etkileşime dâhildir. Uzaktan eğitim ile ilgili tartışmalı konu ise uzaktan eğitimin avantajları ve dezavantajlardır. İletişim teknolojilerinin gelişmesiyle birlikte uzaktan eğitim uygulamalarının yaygınlaştığ görülmektedir. Uzaktan eğitim uygulamalarının diğer bir yaygınlaşma nedeni ise avantajlı olmasından kaynaklanmaktadır. Yapılan araştırmalarda uzaktan eğitimin avantajlarından ön plana çıkanları: dezavantajlı öğrenci grubu öğrencilere eğitim firsatı sağlaması, sistematik ve planlı bir şekilde yürütülmesi, mekan ve zaman yönünden esneklik sağlaması ve öğrenci merkezli olmasıdır. Bunun yanı sıra her eğitim modelinin avantajları olduğu gibi 
dezavantajları da mevcuttur. Dezavantajları ise öğrenen ve öğretici için gerekli yeterliklerin sağlanamaması, tekonolojik alt yapı eksikliği, internet ve dijital araçların maliyetidir. Burada yeterlik hem maddi açıdan hem de hazırbulunuşluk açısından değerlendirilebilir.

COVID-19 salgınıyla birlikte Türkiye'de de yüz yüze eğitimden uzaktan eğitime geçişte Milli Eğitim Bakanlığı (MEB) üç farklı yöntem izlemiştir. İlk yöntem uzaktan eğitime herkesin ulaşabilmesi için her kademeye yönelik Eğitim Bilişim Ağı (EBA) televizyonların kurulması ikinci yöntem ise EBA platformu üzerinden ders öğretmenleri aracılığılla, üçüncüsü ise öğretmenlerin kendi imkanlarıyla farklı platformlar (zoom, watsapp, google meet vb.) kullanarak derslerin işlenmesidir. MEB bu şekilde uzaktan eğitime katılımı yüz yüze eğitimdeki katılım oranına eşitlemeye çalışmıştır. Yükseköğretimde ise uzaktan eğitim uygulamaları çevrimiçi ortam sağlayan yazılımlar ile yürütülmüştür. Bu yazılımlar sayesinde yükseköğretimde uzaktan eğitim çevrimiçi eş zamanlı, çevrimdışı eş zamansız ve karma yöntem şeklinde yürütülmüştür (Kurnaz ve Serçemeli, 2020). Bunun yanı sira sunu dosyalarının oluşturulması, ders içeriklerinin paylaşımı ve derslerin sisteme yüklenmesi, anlık soru sorma ve geribildirim verme, ödev paylaşımı gibi yöntemler de kullanılmıştır. Ölçme ve değerlendirme işlemleri ise genellikle ödev, proje, çevrimiçi sınav ve kısa sınav şeklinde gerçekleştirilmiştir.

Alanyazında uzaktan eğitimle ilgili çalışmalar COVID-19 salgınından önce eğitimdeki teknolojik gelişmelere bağlı olarak gerçekleştirilmiştir. Nitekim yapılan çalışmalara bakıldığında çalışmaların çevrimiçi online eğitim ve teknoloji kullanımına yönelik yapıldığı görülmektedir (Bozkurt ve diğerleri, 2015; Durak ve diğerleri, 2017; Horzum, 2013; Salar, 2009). Öte yandan Gökçe (2008) çalışmasında uzaktan eğimle ilgili çalışmaların çeşitli platformlarda tartışıldığını ve gelecekte de tartışılmaya devam edileceğini belirtmiştir ayrıca uzaktan eğitim ile ilgili yapılan tartışmaların konu bakımından çeşitlilik gösterdiğini söylemiştir. Baki ve diğerleri (2009) çalışmasında uzaktan eğitimin üniversitelerdeki gerekliliğine değinmiştir. COVID 19 salgınından sonra ise çalışmalar salgın döneminde zorunlu ve hızlı bir şekilde uzaktan eğitime geçiş (Özcan, Tosun ve Eken, 2020) ve uzaktan eğitim hakkında paydaşların görüşleri (Adıgüzel, 2020; Demir ve Özdaş, 2020; Kurnaz, Kaynar, Barışık ve Doğrukök, 2020) üzerine yoğunlaşmıştır. Bu süreçte paydaşların görüşlerinin alınması ve sürecin nasıl ilerlediği konusunda çalışmaların sürmesi devam etmektedir. Uzaktan eğitimle ilgili çalışmalar üniversite kademesinde tartış1lırken günümüzde COVID-19 salgınından sonra kapsamı işlevi ve eğitim kademesi olarak genişlemiştir. Nitekim Milli Eğitim Bakanlığı (MEB) ve Yüksek Öğretim Kurulu (YÖK) tüm sinıflarda uzaktan eğitimle eğitim öğretim sürecinin devam edeceğini duyurmuştur. MEB daha sonra salgın sürecinden sonra yüz yüze eğitim başlasa bile uzaktan eğitime de devam edileceğini söylemiştir. Tüm bu durumlar dikkate alındığında çalışmanın amacı uzaktan eğitime ilişkin öğretmen görüşlerini objektif (tarafsız) bir şekilde ortaya koymaktır.

COVID-19 salgınından sonra eğitim öğretim sürecinde yaygınlaşan uzaktan eğitimin paydaşları olan öğrenci ve öğretmenlerin süreçte yaşadıkları olumlu ve olumsuz etkileri ortaya çıkarmak alınacak önlemler açısından önemlidir. Salgın sürecinde uzaktan eğitim uygulamalarına yönelik Tükçe öğretmenlerinin (Karacaoğlu, Karakuş, Esendemir ve Ucuzsatar, 2021), Matematik öğretmenlerinin (Tican ve Gökoğlu, 2021), Fen Bilimleri öğretmenlerinin (Bakioğlu ve Çevik, 2020) uzaktan eğitim hakkında görüşlerini alan çalışmalar mevcuttur. Ancak tüm branş öğretmenlerinin görüşleri ile ilgili çalışma bulunmakatadır. Bu bağlamda uzaktan eğitime ilişkin en önemli paydaşı olan ve uygulamaya katılan tüm baranş öğretmenlerinin görüşlerini ortaya koymak araştırmanın önemini ortaya koymaktadır.

\subsection{Problem Durumu}

Uzaktan eğitime ilişkin öğretmenlerin görüşlerini ortaya koymak için araştırmanın nicel ve nitel problemleri şu şekilde sıralanmıştır: 
1. Öğretmenlerin uzaktan eğitime ilişkin görüşleri ne düzeydedir ?

2. Öğretmenlerin uzaktan eğitime ilişkin görüşleri hakkında cinsiyet değişkenine göre anlamlı fark var midir?

3. Öğretmenlerin uzaktan eğitime ilişkin görüşleri hakkında mesleki kıdem değişkenine göre anlamlı bir farklılık var mıdır?

4. Öğretmenlerin uzaktan eğitime ilişkin görüşleri hakkında görev yeri değişkenine göre anlamlı bir farklılık var mıdır?

5. Öğretmenlerin uzaktan eğitime ilişkin görüşleri hakkında uzaktan eğitimle ders verme değişkenine göre anlamlı bir farklılık var mıdır?

6. Öğretmenlerin uzaktan eğitime ilişkin görüşleri hakkında COVID-19 salgınından önce uzaktan eğitimle ders verme değişkenine göre anlamlı bir farklılık var mıdır?

7. Öğretmenlerin uzaktan eğitiminin hakkındaki görüşleri nelerdir?

\section{YÖNTEM}

\subsection{Araştırmanın Modeli}

$\mathrm{Bu}$ araştırmada karma yöntem araştırma modeli olan yakınsayan paralel desen kullanılmıştır. Yakınsayan paralel desende nicel ve nitel aşamaları araştırma süreci eş zamanlı olarak uygulanmaktadır (Creswell ve Plano Clark, 2014). Bu desende veriler analiz edilirken nicel ve nitel veriler ayrı ayrı analiz edilir. Elde edilen sonuçlar yorumlanırken birleştirilerek yapilır.

\subsection{Evren Örneklem}

Araştırma katılımc1 grubunun nicel bölüm çalışma evreni 2020-2021 eğitim öğetim yılında Konya ilinde MEB'e bağlı resmi okullarda (ilkokul, ortaokul ve liselerde) görev yapan ve uzaktan eğitim uygulamalarına katılan öğretmenler oluşturmaktadır. Çalışmada evrenin geniş olması nedeniyle sınırlı bir çalışma grubunun belirlenmesi yoluna gidilmiştir. Bu amaçla kolay ulaşılabilir durum örneklemesi yoluyla, Konya ili merkezi ve taşra ilçelerinde bulunan okullarda görev yapan öğretmenler anket uygulanmıştır. Nicel araştırmaya (ankete) katılan öğretmenlerin sosyo demografik özellikleri Tablo 1'de gösterilmiştir.

Tablo 1. Nicel Katılımcı Grubu Frekans ve Yüzde Tablosu

\begin{tabular}{llll}
\hline Demografik Özellikler & & Frekans $(f)$ & Yüzde (\%) \\
\hline \multirow{2}{*}{ Cinsiyet } & Bay & 89 & 30,48 \\
& Kadın & 203 & 69,52 \\
\hline \multirow{2}{*}{ Görev Yeri } & Köy/mahalle & 50 & 17,12 \\
& İlçe & 119 & 40,75 \\
& İl & 123 & 42,13 \\
\hline \multirow{2}{*}{ Mesleki Kıdem } & $1-5$ & 58 & 41,44 \\
& $6-10$ & 69 & 28,42 \\
& $11-15$ & 46 & 25,34 \\
\multirow{2}{*}{ Uzaktan Eğitim } & 15 ve sonra & 119 & 4,80 \\
\hline Uzaktan Eğitim & Evet & 256 & 87,67 \\
(COVID-19 öncesi) & Hayır & 36 & 12,33 \\
\hline
\end{tabular}

Araştırmanın nitel katılımcı grubu maksimum çeşitlilik örnekleme yöntemi kullanılarak 8 öğretmen ile gerçekleştirilmiştir. Maksimum çeşitlilik örneklemesinin amacı, farklı özelliklere sahip bir örneklem grubu belirleyerek araştırma problemi ya da durumla alakalı farklılıkların ve benzerliklerin derinlemesine incelenmesidir (Yıldırım ve Şimşek, 2018). Bu doğrultuda, cinsiyet, branş, mesleki kıdem, görev yeri, uzaktan eğitimle ders verme ve COVID-19 salgını öncesi uzaktan eğitimle ders verme gibi değişkenler açısından çeşitlilik 
içeren örneklem grubu oluşturulmuştur. Görüşmeye katılan öğretmenlerin özellikleri Tablo 2'de gösterilmiştir.

Tablo 2. Nitel Çalışma Grubu Özellikleri

\begin{tabular}{lllllll}
\hline Katılımc1 & Cinsiyet & Branş & Kidem & Görev Yeri & $\begin{array}{l}\text { Uzaktan } \\
\text { Eğitim }\end{array}$ & $\begin{array}{l}\text { Uzaktan } \\
\text { Eğitim } \\
\text { (COVID-19 } \\
\text { Öncesi) }\end{array}$ \\
\hline Ö1 & Bay & Türkçe & & & Evet & Hayır \\
Ö2 & Bay & Din Kültürü & 16 & İlçe & Evet & Hayır \\
Ö3 & Kadın & Din Kültürü & 4 & Köy/Mahalle & Evet & Evet \\
Ö4 & Bay & İlköğretim Matematik & 4 & İlçe & Evet & Hayır \\
Ö5 & Bay & Özel Eğitim & 6 & İl & Evet & Hayır \\
Ö6 & Bay & Fen Bilimleri & 15 & İlçe & Evet & Hayır \\
Ö7 & Kadın & İngilizce & 1 & Köy/mahalle & Evet & Hayır \\
Ö8 & Kadın & Rehberlik & 2 & İlçe & Evet & Evet \\
\hline
\end{tabular}

\subsection{Veri Toplama Araçları}

Araştırmada eş zamanlı olarak iki çeşit veri toplama aracı kullanılmıştır. Uzaktan Eğitime İlişkin Görüş Anketi araştırmanın nicel veri toplama aracını oluşturmaktadır. Anket iki bölümden oluşmaktadır. Birinci bölümde katılımcılara ait demografik bilgiler ikinci bölümünde ise öğretmenlerin uzaktan eğitime ilişkin görüşleri ile ilgili bilgiler toplanmıştır. Öğretmen görüşlerini almak için 5'li likert tipi 32 maddeye yer verilmiştir. Anket maddeleri hazırlanması sürecinde uzaktan eğitimle ilgili literatür taranmış, katılımcılarla görüşmeler gerçekleştirilmiştir. Anketin kapsam geçerliliğini sağlamak için 5 alan uzmanından uzman görüşü alınmıştır. Yine kapsam geçerliliğini sağlamak adına anket maddelerinin anlaşılırlığını sağlamak için 16 öğretmenin görüşü alınarak pilot uygulama gerçekleştirilmiştir. Anket maddeleri uzaktan eğitimin farklı özelliklerini ölçmeye yönelik hazırlanması için maddeler tek tek kontrol edilmiştir. Bundan dolayı ankette yapı geçerliliği için faktör analizi ve güvenirliği için iç tutarlılık çalışması yapılmamıştır.

Uzaktan eğitime ilişkin öğretmen görüşlerini almak için yarı yapılandırılmış görüşme formu ise araştırmanın nitel veri toplama aracını oluşturmaktadır. Yine yarı yapılandırılmış görüşme formunun hazırlanması aşamasında literatür incelenmiş ve hedef kitle ile ön görüşmeler yapılmış ve görüşme için taslak bir form oluşturulmuştur. Görüşmelerde katılımcılara uzaktan eğitime ilişkin şu sorular sorulmuştur:

1. Uzaktan eğitimin size göre avantajları ve dezavantajları nelerdir?

2. Uzaktan eğitim faaliyetlerinde okul idaresinin yönetimi hakkındaki görüşleriniz nelerdir?

3. Uzaktan eğitimin her alanda uygulanabileceğini düşünüyor musunuz? Niçin?

4. Uzaktan eğitim faaliyetlerinin her kademe (ana sinıfi, ilkokul, ortaokul ve lise) uygulanabileceğini düşünüyor musunuz?

5. Uzaktan eğitimde teknoloji ve teknolojik alt yapıya ilişkin görüşleriniz nelerdir?

6. Uzaktan eğitim 'eğitimde firsat eşitliğini'” ilkesini karşılamakta mıdır?

7. Uzaktan eğitimin zararları var mıdır? Varsa hangi konularda zararlı olduğunu düşünüyorsunuz?

$\mathrm{Bu}$ sorulara ek olarak katılımcıların, maliyet, zaman, katılım, altyapı, hazırbulunuşluk, gelişim özellikleri gibi konular açısından uzaktan eğitim değerlendirmelerinin istendiği sonda ya da tamamlayıcı nitelikte sorular sorulmuştur. 


\subsection{Verilerin toplanması}

Çalışmanın nicel ve nitel verileri 2020-2021 eğitim öğretim yılının 2. döneminde toplanmıştır. Uzaktan eğitime ilişkin öğretmen görüşleri anketi katılımcılara araştırmacılar tarafından uygulanmıştır. Katılımcılarla yapılan görüşmeler ise yüz yüze gerçekleştirilmiştir. Görüşmeler gerek ses kaydı tutularak gerekse yazılı not alınarak kaydedilmiştir.

\subsection{Verilerin Analizi}

Araştırmada kullanılan uzaktan eğitime ilişkin öğretmen görüş anketinden elde edilen veriler Jamovi-1.6.15 programıla analiz edilmiştir. Veriler şu şekilde puanlanmıştır: kesinlikle kat1lmiyorum 1.00-1.80, kat1lmiyorum 1.81-2.60, k1smen kat1lyorum 2.61-3.40, kat1liyorum 3.41-4.20 ve kesinlikle katıliyorum 4.21-5.00. Araştırmanın birinci alt problemine ilişkin verilerin analizinde öğretmen görüşlerinin ortalamasına bakarak karar verilmiştir. Çalışmanın diğer nicel alt problemlerinde ise her madde için fark analizleri yapılmıştır. Fark analizlerinde nonparametrik testler olan Mann Whitney U ve Kruskal Wallis testleri kullanılmış ve anlamlılık düzeyi .05 olarak alınmıştır.

Araştırmanın nitel kısmında çalışmanın inandırıcılığını artırmak amacıyla öğretmenler ile uzaktan eğitim hakkında derinlemesine görüşmeler yapılmış ve görüşler teyit edilmiştir. Görüşmelerden elde edilen verilere içerik analizi yapılmıştır. Çalışmada nitel kısmının aktarılabilirliği ise katılımcı çeşitliliği ve ayrıntılı olarak betimleme ile sağlanmıştır. Ayrıntılı betimlemenin bir gereği olarak bulgular kodlama ve kaynak sayıları belirtilerek grafik ve şekiller haline getirilmiştir. İçerik analizi kapsamında ilk önce veriler kodlanmış, kodlanan veriler aracıllğıyla temalar elde edilmiş ve temalar ve kodlar düzenlenmiştir sonra elde edilen bulgular tanımlanmış ve yorum yapılmıştır (Yıldırım ve Şimşek, 2018). Analiz sürecinde elde edilen kod ve temalar her iki araştırmacı tarafından karşılaştırılarak tutarlılık sağlanmaya çalışılmıştır. Ayrıca yapılan kodlamalar ve oluşturulan temalar tutarlılık incelemesi yapılmak üzere iki uzmana gönderilmiş̧ir. Yapılan analizler incelendiğinde, iki kişinin yaptığı 31 kod ve tema analizden 26'inin aynı olduğu tespit edilmiştir. Araştırmanın güvenilirlik hesaplaması ise Miles ve Huberman'ın (1994) önerdiği güvenirlik formülüne göre; Uzlaşma Yüzdesi = Görüş Birliği / (Görüş Birliği + Görüş Ayrılığı)x100 yapılmıştır ve \%83.87 oranında görüş birliğine varılmıştır. Alınan dönütler doğrultusunda kodlamalar düzenlenmiştir. Araştırmada katılımcıların gerçek isimleri kullanılmamış ' Ö', şeklinde kodlanmıştır.

\section{BULGULAR}

Uzaktan eğitime ilişkin öğretmen görüşleri çalışmasının birinci alt probleme ait bulgulardan öğretmenlerin uzaktan eğitime ilişkin görüşlerine ilişkin betimsel istatistikler Tablo 3'te gösterilmiştir.

Tablo 3. Uzaktan Eğitim Görüş Anketi Betimsel İstatistikleri

\begin{tabular}{llll}
\hline Madde & $\overline{\mathrm{x}}$ & ss & Düzeyi \\
\hline M1 & 1.95 & .973 & Katılmiyorum \\
M2 & 2.54 & 1.13 & Kat1lmiyorum \\
M3 & 2.43 & 1.20 & Kat1lmiyorum \\
M4 & 2.91 & 1.13 & Kismen Kat1lyorum \\
M5 & 3.03 & 1.12 & Kismen Kat1lyorum \\
M6 & 2.84 & 1.25 & Kismen Kat1lyorum \\
M7 & 4.35 & .921 & Kesinlikle Kat1lyorum \\
M8 & 4.31 & .932 & Kesinlikle Kat1liyorum \\
M9 & 4.23 & .964 & Kesinlikle Kat1liyorum \\
M10 & 1.75 & .980 & Kesinlikle Kat1lmiyorum
\end{tabular}




\begin{tabular}{|c|c|c|c|}
\hline M11 & 3.55 & .985 & Katıliyorum \\
\hline M12 & 3.34 & 1.04 & Kismen Kat1liyorum \\
\hline M13 & 3.46 & 1.12 & Kat1liyorum \\
\hline M14 & 2.92 & 1.05 & Kismen Kat1liyorum \\
\hline M15 & 4.02 & 1.13 & Kat1liyorum \\
\hline M16 & 3.53 & 1.09 & Kat1liyorum \\
\hline M17 & 3.24 & 1.09 & Kismen Katıliyorum \\
\hline M18 & 3.41 & 1.03 & Katıliyorum \\
\hline M19 & 2.79 & 1.19 & Kismen Katıliyoum \\
\hline M20 & 2.42 & 1.20 & Katılmiyorum \\
\hline M21 & 4.38 & .929 & Kesinlikle Katıliyorum \\
\hline M22 & 2.88 & 1.04 & Kismen Kat1liyorum \\
\hline M23. & 2.53 & 1.10 & Katılmiyorum \\
\hline M24 & 3.08 & 1.26 & Kismen Kat1liyorum \\
\hline M25 & 3.57 & 1.31 & Kat1liyorum \\
\hline M26 & 3.77 & 1.38 & Katıliyorum \\
\hline M27 & 3.65 & .989 & Kat1liyorum \\
\hline M28 & 4.32 & .844 & Kesinlikle Katıliyorum \\
\hline M29 & 3.13 & 1.18 & K1smen Kat1liyorum \\
\hline M30 & 3.81 & .935 & Katıliyorum \\
\hline M31 & 3.93 & .892 & Katılıyorum \\
\hline M32 & 3.92 & 1.16 & Katılıyorum \\
\hline
\end{tabular}

Tablo 3 ’te görüldüğü üzere katılımcıların "M10. Uzaktan eğitimle öğrencilerde ögrrenme güçlükleri yüz yüze eğitime göre daha kolay çözülür " görüşüne verilen cevapların aritmetik ortalaması $(\overline{\mathrm{X}}=1.75)$ 1.00-1.80 aralığını karşılamaktadır. Bu durum öğretmenlerin kesinlikle katılmıyorum ifadesine karş1lık gelmektedir.

Katılımcıların "M1-Uzaktan eğitimin eğitimde firsat eşitliği sağlar" görüşüne verilen cevapların aritmetik ortalaması $(\overline{\mathrm{X}}=1.95)$ 1.81-2.60 aralığını karşılamaktadır. $\mathrm{Bu}$ durum katılımcıların katılmıyorum ifadesini karşılamaktadır. Katılımcıların "M2. Uzaktan eğitim geniş ögrenci kitlelerine ulaşma imkânı sağlar" görüşüne verilen cevapların aritmetik ortalaması $(\overline{\mathrm{X}}=2.54)$ 1.81-2.60 aralığını karşılamaktadır. Bu durum katılımcıların katılmıyorum ifadesini karşılamaktadır. Katılımcıların "M3. Uzaktan ĕgitim her kademede ögrenciye verilebilir" görüşüne verilen cevapların aritmetik ortalaması $(\overline{\mathrm{X}}=2.43)$ 1.81-2.60 aralığına karşılamakta olup katılmıyorum ifadesini belirtmektedir. Katılımcıların "M20. Uzaktan eğitimin her yerden ulaşılabilir olduğunu düşünüyorum" görüşüne verilen cevapların aritmetik ortalamas1 $(\overline{\mathrm{X}}=2.42)$ 1.81-2.60 aralığına karşılamakta olup katılmıyorum ifadesini belirtmektedir. Katılımcıların "M23. Uzaktan eğitimle herkese uygun ögrenme yöntemi oluşturulabilir" görüşüne verilen cevapların aritmetik ortalaması $(\bar{X}=2.53)$ 1.81-2.60 aralığına karş1lamakta olup katılmıyorum ifadesini belirtmektedir.

Katılımcıların "M4. Uzaktan eğitimle bilgiye kolayca ulaşılır" görüşüne verilen cevapların aritmetik ortalaması $(\overline{\mathrm{X}}=2.91)$ 2.61-3.50 aralığına karşılamakta olup kısmen katıllyorum ifadesini belirtmektedir. Katılımcıların "M 5. Uzaktan eğitimle bilgiye hizlıca ulaşılır" görüşüne verilen cevapların aritmetik ortalaması $(\overline{\mathrm{X}}=3.03)$ 2.61-3.50 aralığına karşılamakta olup kısmen katıliyorum ifadesini belirtmektedir. Katılımcıların "M 6. Uzaktan eğitim öğrencilerin okul ortamına ihtiyaç olmadan ĕ̌itim alma firsatını sağlamaktadır" görüşüne verilen cevapların aritmetik ortalaması $(\overline{\mathrm{X}}=2.84)$ 2.61-3.50 aralığına karşılamakta olup kısmen katıliyorum ifadesini belirtmektedir. Katılımcıların "M 12. Uzaktan eğitim platformlarını (Zoom, Teamlink, Google Meet vb.) kullanmak için ögrencilerin eğitim alması gerekir" görüşüne verilen cevapların aritmetik ortalaması $(\bar{X}=3.34) 2.61-3.50$ aralığına 
karş1lamakta olup kısmen katıllyorum ifadesini belirtmektedir. Katılımcıların "M 14. Uzaktan eğitimle bilgi birikimi kolay bir şekilde aktarılabilir" görüşüne verilen cevapların aritmetik ortalaması ( $\overline{\mathrm{X}}=2.92)$ 2.61-3.50 aralığına karşılamakta olup kismen katıllyorum ifadesini belirtmektedir. Katılımcıların "M17. Uzaktan ĕgitim öğrenciler üzerinde ögrenme deneyimi sağlamaktadır" görüşüne verilen cevapların aritmetik ortalaması $(\overline{\mathrm{X}}=3.24)$ 2.61-3.50 aralı̆̆ına karşılamakta olup klsmen katılıyorum ifadesini belirtmektedir. Katılımcıların "M19. Uzaktan eğitim daha düşük maliyetle öğrenme ve ögretme süreci sağlar" görüşüne verilen cevapların aritmetik ortalaması $(\overline{\mathrm{X}}=2.79) \quad 2.61-3.50$ aralığına karşılamakta olup kismen katıllyorum ifadesini belirtmektedir. Katılımcıların "M 22. Uzaktan eğitim tek noktadan mobil uyum ile kolayca yönetim sağlar" görüşüne verilen cevapların aritmetik ortalaması $(\overline{\mathrm{X}}=2.88)$ 2.61-3.50 aralığına karşılamakta olup kısmen katılıyorum ifadesini belirtmektedir. Katılımcıların "M 24. Zaman esnekliği bakımından yüz yüze eğitime göre daha avantajlıdır" görüşüne verilen cevapların aritmetik ortalaması $(\overline{\mathrm{X}}=3.08)$ 2.61-3.50 aralığına karş1lamakta olup kısmen katılıyorum ifadesini belirtmektedir. Katılımcıların "M 29. Uzaktan eğitim velilerin eğitim masraflarını artırır" görüşüne verilen cevapların aritmetik ortalamas1 ( $\overline{\mathrm{X}}=3.13)$ 2.61-3.50 aralığına karşılamakta olup kısmen katıllyorum ifadesini belirtmektedir.

Katılımcıların "M 11. Uzaktan eğitim platformları (Zoom, Teamlink, Google Meet vb.) kolay bir şekilde kullanılabilir" görüşüne verilen cevapların aritmetik ortalaması $(\overline{\mathrm{X}}=3.55)$ 3.41- 4.20 aralığına karşılamakta olup katılyyorum ifadesini belirtmektedir. Katılımcıların "M13. Uzaktan eğitim platformlarını (Zoom, Teamlink, Google Meet vb.) kullanmak için ögretmenlerin eğitim alması gerekir" görüşüne verilen cevapların aritmetik ortalaması $(\overline{\mathrm{X}}=3.55) \quad 3.41-4.20$ aralığına karşılamakta olup katıllyorum ifadesini belirtmektedir. Katılımcıların "M15. Her ders uzaktan eğitimle (Beden eğitimi, müzik vb.) gerçekleştirilmez" görüşüne verilen cevapların aritmetik ortalaması $(\bar{X}=4.02)$ 3.41-4.20 aralığına karşılamakta olup katıllyorum ifadesini belirtmektedir. Kat1lımcıların "M16. Uzaktan eğitim, günümüz dünyasında zorunluluk haline gelmiștir" görüșüne verilen cevapların aritmetik ortalaması $(\bar{X}=3.53) \quad 3.41-4.20$ aralığına karşılamakta olup katıllyorum ifadesini belirtmektedir. Katılımcıların "M18. Uzaktan ĕgitim öğretmenler üzerinde ögrenme deneyimi sağlamaktadır" görüşüne verilen cevapların aritmetik ortalamas1 $(\bar{X}=3.41)$ 3.41-4.20 aralığına karş1lamakta olup katıllyorum ifadesini belirtmektedir. Katılımcıların "M25. Sinlf yönetiminin uzaktan eğitimde daha zor olduğunu düşünüyorum" görüşüne verilen cevapların aritmetik ortalamas1 $(\overline{\mathrm{X}}=3.57)$ 3.41-4.20 aralığına karşılamakta olup katıllyorum ifadesini belirtmektedir. Katılımcıların "M26. Akademik başarl, yüz yüze eğitimde uzaktan eğitime göre daha iyidir" görüşüne verilen cevapların aritmetik ortalaması $(\overline{\mathrm{X}}=3.77)$ 3.41-4.20 aralığına karşılamakta olup katıllyorum ifadesini belirtmektedir. Katılımciların "M27. Uzaktan eğitim platformlarında çoğu zaman sıkıntı yaşanır" görüşüne verilen cevapların aritmetik ortalaması ( $\overline{\mathrm{X}}=3.65)$ 3.414.20 aralığına karşılamakta olup katıllyorum ifadesini belirtmektedir. Katılımcıların "M30. Uzaktan ĕ̆itim öğrencilerin mobil ögrenme ortamlarında istenmedik davranışlar kazanmasına neden olabilir" görüșüne verilen cevapların aritmetik ortalaması $(\overline{\mathrm{X}}=3.81)$ 3.41-4.20 aralığına karş1lamakta olup katıllyorum ifadesini belirtmektedir. Katılımcıların "M 31. Uzaktan eğitimde oluşabilecek güvenlik açıkları tehlike arz edebilir" görüşüne verilen cevapların aritmetik ortalaması ( $\overline{\mathrm{X}}=3.93)$ 3.41-4.20 aralığına karşılamakta olup katıllyorum ifadesini belirtmektedir. Katılımcıların "M32. Uzaktan eğitim öğretmenin iş yükünü artırır" görüşüne verilen cevapların aritmetik ortalaması $(\overline{\mathrm{X}}=3.92)$ 3.41-4.20 aralığına karşılamakta olup katıllyorum ifadesini belirtmektedir.

Katılımcıların "M 7. Uzaktan eğitimde bilgisayarın başında uzun süre kalındığından dolayı sağlık problemleri oluşturabilir" görüşüne verilen cevapların aritmetik ortalaması $(\overline{\mathrm{X}}=$ 4.35) 4.21-5.00 aralığına karşılamakta olup kesinlikle katılıyorum ifadesini belirtmektedir. Katılımcıların "M 8. Uzaktan eğitimle internet erişimi açısından problemler oluşturmaktadır" görüşüne verilen cevapların aritmetik ortalaması $(\overline{\mathrm{X}}=4.31)$ 4.21-5.00 aralığına karşılamakta olup kesinlikle katılyyorum ifadesini belirtmektedir. Katılımcıların " $M$ 9. Uzaktan eğitim ögrencilerin sosyalleşmesine engel oluşturmaktadır" görüşüne verilen cevapların aritmetik 
ortalaması $(\overline{\mathrm{X}}=4.23)$ 4.21-5.00 aralığına karşılamakta olup kesinlikle katıllyorum ifadesini belirtmektedir. Katılımcıların "M 21. Alt yapı nedeniyle kirsal kesimlerde erişim problemi oluşturur" görüşüne verilen cevapların aritmetik ortalaması $(\bar{X}=4.38)$ 4.21-5.00 aralığına karşılamakta olup kesinlikle katıllyorum ifadesini belirtmektedir. Katılımcıların "M28. Uzaktan eğitimle yapılan sinavların güvenirliğinde sıkıntı vardır" görüşüne verilen cevapların aritmetik ortalaması $(\overline{\mathrm{X}}=4.32)$ 4.21-5.00 aralığına karşılamakta olup kesinlikle katıllyorum ifadesini belirtmektedir.

Uzaktan eğitime ilişkin öğretmen görüş çalışmasında ikinci alt probleme ait bulgulardan öğretmenlerin cinsiyet değişkenine göre görüşleri arasında anlamlı farklılık çıkan maddelere ilişkin bulgular Tablo 4'te gösterilmiştir.

Tablo 4. Cinsiyet Değişkenine Göre Mann Whitney U Testi Bulguları

\begin{tabular}{|c|c|c|c|}
\hline Madde & Değişken & $\mathrm{p}$ & $\mathrm{U}$ \\
\hline 14. Uzaktan eğitimle bilgi birikimi kolay bir şekilde aktarılır. & $\begin{array}{l}\text { Bay }(\mathrm{N}=89) \\
\text { Kadin }(\mathrm{N}=203)\end{array}$ & .041 & 7736 \\
\hline $\begin{array}{l}\text { 19. Uzaktan eğitim daha düşük maliyetle öğrenme ve } \\
\text { öğretme süreci sağlar. }\end{array}$ & $\begin{array}{l}\text { Bay }(\mathrm{N}=89) \\
\text { Kadın }(\mathrm{N}=203)\end{array}$ & .014 & 7452 \\
\hline $\begin{array}{l}\text { 22. Uzaktan eğitim tek noktadan mobil uyum ile kolayca } \\
\text { yönetim sağlar. }\end{array}$ & $\begin{array}{l}\text { Bay }(\mathrm{N}=89) \\
\text { Kadin }(\mathrm{N}=203)\end{array}$ & .016 & 7505 \\
\hline $\begin{array}{l}\text { 23. Uzaktan eğitimle herkese uygun öğrenme yöntemi } \\
\text { oluşturulabilir. }\end{array}$ & $\begin{array}{l}\text { Bay }(\mathrm{N}=89) \\
\text { Kadın }(\mathrm{N}=203)\end{array}$ & .014 & 7455 \\
\hline
\end{tabular}

Tablo 4'te görüldüğü gibi katılımcilar öğretmenlerin uzaktan eğitimle bilgi birikiminin kolay bir şekilde aktarılmasına yönelik bay $(\overline{\mathrm{X}}=3.11)$ ile kadınlar $(\overline{\mathrm{X}}=2.84)$ arasında bayların lehine istatiksel olarak anlamlı bir farklılık bulunmuştur $(U=7736, p=.041<.05)$. Katılımcıların uzaktan eğitimin daha düşük maliyetle öğrenme ve öğretme süreci sağlamasına yönelik görüşlerinde cinsiyet değişkenine göre bay $(\overline{\mathrm{X}}=3.24)$ ile kadınlar $(\overline{\mathrm{X}}=2.67)$ arasında bayların lehine yönelik istatiksel olarak anlamlı farkl1lı bulunmuştur $(\mathrm{U}=7452, \mathrm{p}=.014<.05)$. Katılımcıların uzaktan eğitimin tek noktadan mobil uyum ile kolayca yönetim sağlamasına yönelik görüşlerinde bay $(\overline{\mathrm{X}}=3.09)$ ile kadınlar $(\overline{\mathrm{X}}=2.79)$ arasında bayların lehine istatiksel olarak anlamlı bir farklılık bulunmuştur $(\mathrm{U}=7505, \mathrm{p}=.016<.05)$. Katılımcıların uzaktan eğitimle herkese uygun öğrenme yöntemi oluşturulabilmesine yönelik görüşlerinde cinsiyet değişkenine göre bay $(\overline{\mathrm{X}}=2.79)$ ile kadınlar $(\overline{\mathrm{X}}=2.42)$ arasında bayların lehine yönelik istatiksel olarak anlamlı farkl11ık bulunmuştur $(\mathrm{U}=7455, \mathrm{p}=.014<.05)$.

Uzaktan eğitime ilişkin öğretmen görüş çalışmasında üçüncü alt probleme ait bulgulardan öğretmenlerin mesleki kıdem değişkenine göre görüşleri arasında anlamlı farklılık çıkan maddelere ilişkin bulgular Tablo 5'te gösterilmiştir.

Tablo 5. Kıdem Durumuna Göre Yapılan Kruskall Wallis H Testine Ait Bulgular

\begin{tabular}{|c|c|c|c|c|c|}
\hline Madde & $\begin{array}{l}\text { Mesleki } \\
\text { Kidem (Y1) }\end{array}$ & $x^{2}$ & df & $\mathrm{p}$ & $\mathrm{U}$ \\
\hline \multirow{4}{*}{$\begin{array}{l}\text { 4. Uzaktan eğitimle bilgiye kolayca } \\
\text { ulaşılır. }\end{array}$} & $1-5$ & \multirow{4}{*}{8.779} & \multirow{4}{*}{3} & \multirow{4}{*}{.032} & $1<3(\mathrm{U}=3.718)$ \\
\hline & $6-10$ & & & & \\
\hline & $11-15$ & & & & \\
\hline & 15 ve sonrası & & & & \\
\hline \multirow{4}{*}{$\begin{array}{l}\text { 8. Uzaktan eğitimle internet erişimi } \\
\text { açısından problemler oluşturmaktadır. }\end{array}$} & $1-5$ & \multirow{4}{*}{10.809} & \multirow{4}{*}{3} & \multirow{4}{*}{.013} & $1>4(\mathrm{U}=-3.870)$ \\
\hline & $6-10$ & & & & \\
\hline & $11-15$ & & & & \\
\hline & 15 ve sonras 1 & & & & \\
\hline 11. Uzaktan eğitim platformları (Zoom, & $1-5$ & 11.944 & 3 & .008 & $1<4(\mathrm{U}=4.649)$ \\
\hline
\end{tabular}




\begin{tabular}{|c|c|c|c|c|c|}
\hline $\begin{array}{l}\text { Teamlink, Google Meet vb.) kolay bir } \\
\text { şekilde kullanılabilir. }\end{array}$ & $\begin{array}{l}6-10 \\
11-15 \\
15 \text { ve sonras }\end{array}$ & & & & \\
\hline $\begin{array}{l}\text { 12. Uzaktan eğitim platformlarını } \\
\text { (Zoom, Teamlink, Google Meet vb.) } \\
\text { kullanmak için öğrencilerin eğitim } \\
\text { alması gerekir. }\end{array}$ & $\begin{array}{l}1-5 \\
6-10 \\
11-15 \\
15 \text { ve sonrası }\end{array}$ & 21.457 & 3 & .001 & $\begin{array}{l}1>4(\mathrm{U}=-6.083) \\
2>4(\mathrm{U}=-3.666)\end{array}$ \\
\hline $\begin{array}{l}\text { 13. Uzaktan eğitim platformlarını } \\
\text { (Zoom, Teamlink, Google Meet vb.) } \\
\text { kullanmak için öğretmenlerin eğitim } \\
\text { alması gerekir }\end{array}$ & $\begin{array}{l}1-5 \\
6-10 \\
11-15 \\
15 \text { ve sonras }\end{array}$ & 15.507 & 3 & .001 & $1>4(\mathrm{U}=-5.29)$ \\
\hline $\begin{array}{l}\text { 14. Uzaktan eğitimle bilgi birikimi kolay } \\
\text { bir şekilde aktarılabilir. }\end{array}$ & $\begin{array}{l}1-5 \\
6-10 \\
11-15 \\
15 \text { ve sonras }\end{array}$ & 8.916 & 3 & .030 & $1<3(\mathrm{U}=3.653)$ \\
\hline $\begin{array}{l}\text { 18. Uzaktan eğitim öğretmenler üzerinde } \\
\text { öğrenme deneyimi sağlamaktadır. }\end{array}$ & $\begin{array}{l}1-5 \\
6-10 \\
11-15 \\
15 \text { ve sonras }\end{array}$ & 8.218 & 3 & .042 & $1<2(\mathrm{U}=3.672)$ \\
\hline $\begin{array}{l}\text { 20. Uzaktan eğitimin her yerden } \\
\text { ulaşılabilir olduğunu düşünüyorum. }\end{array}$ & $\begin{array}{l}1-5 \\
6-10 \\
11-15 \\
15 \text { ve sonras }\end{array}$ & 14.514 & 3 & .002 & $\begin{array}{l}1<2(\mathrm{U}=3.882) \\
1<3(\mathrm{U}=4.528) \\
1<4(\mathrm{U}=4.977)\end{array}$ \\
\hline $\begin{array}{l}\text { 22. Uzaktan eğitim tek noktadan mobil } \\
\text { uyum ile kolayca yönetim sağlar. }\end{array}$ & $\begin{array}{l}1-5 \\
6-10 \\
11-15 \\
15 \text { ve sonras1 }\end{array}$ & 14.168 & 3 & .003 & $1<3(\mathrm{U}=5.019)$ \\
\hline $\begin{array}{l}\text { 23. Uzaktan eğitimle herkese uygun } \\
\text { öğrenme yöntemi oluşturulabilir. }\end{array}$ & $\begin{array}{l}1-5 \\
6-10 \\
11-15 \\
15 \text { ve sonras1 }\end{array}$ & 9.774 & 3 & .021 & $1<3(\mathrm{U}=3.85)$ \\
\hline $\begin{array}{l}\text { 25. Sinıf yönetiminin uzaktan eğitimde } \\
\text { daha zor olduğunu düşünüyorum. }\end{array}$ & $\begin{array}{l}1-5 \\
6-10 \\
11-15 \\
15 \text { ve sonras }\end{array}$ & 18.823 & 3 & .001 & $\begin{array}{l}1>2(\mathrm{U}=0.896) \\
1>3(\mathrm{U}=1.064) \\
3<4(\mathrm{U}=-4.44)\end{array}$ \\
\hline $\begin{array}{l}\text { 27. Uzaktan eğitim platformlarında çoğu } \\
\text { zaman sıkıntı yaşanır. }\end{array}$ & $\begin{array}{l}1-5 \\
6-10 \\
11-15 \\
15 \text { ve sonras1 }\end{array}$ & 15.365 & 3 & .002 & $\begin{array}{l}1>3(\mathrm{U}=5.01) \\
1>4(\mathrm{U}=4.13)\end{array}$ \\
\hline $\begin{array}{l}\text { 32. Uzaktan eğitim öğretmenin iş } \\
\text { yükünü artırır }\end{array}$ & $\begin{array}{l}1-5 \\
6-10 \\
11-15 \\
15 \text { ve sonras1 }\end{array}$ & 11.674 & 3 & .009 & $1>3(\mathrm{U}=4.60)$ \\
\hline
\end{tabular}

Katılımcıların uzaktan eğitimde bilgiye kolayca ulaşılır görüşünde mesleki kıdem değişkenine göre istatistiksel olarak anlamlı bir farkl1lık bulunmuştur $(\chi 2=8.779, \mathrm{p}=.032<.05)$. Sıralar ortalamasına göre 11-15 kıdem grubundaki öğretmenlerin görüşlerinin 1-5 kıdem grubu öğretmen görüşlerine göre olumlu yönde anlamlı farklılık görülmüştür $(\mathrm{U}=3.718)$. Katılımcıların uzaktan eğitimle internet erişimi açısından problemler oluşturmaktadır 
görüşünde mesleki kıdem değişkenine göre istatistiksel olarak anlamlı bir farklılık bulunmuştur $(\chi 2=10.809, \mathrm{p}=.013<.05)$. S1ralar ortalamasına göre $1-5 \mathrm{k} 1 \mathrm{dem}$ grubundaki öğretmenlerin görüşlerinin 15 ve sonrası kıdem grubu öğretmen görüşlerine göre olumsuz yönde anlamlı farklılık görülmüştür $\left(\mathrm{U}_{1-3}=-3.870\right)$. Kat1lımc1ların Uzaktan eğitim platformlar (Zoom, Teamlink, Google Meet vb.) kolay bir şekilde kullanılabilir görüşünde mesleki kıdem değişkenine göre istatistiksel olarak anlamlı bir farklıl1k bulunmuştur $(\chi 2=11.944$, $\mathrm{p}=.008<.05)$. Siralar ortalamasına göre 15 ve sonrası kıdem grubundaki öğretmenlerin görüşlerinin 1-5 k1dem grubu öğretmen görüşlerine göre olumlu yönde anlamlı farklılık görülmüştür (U=4.649). Katılımcıların Uzaktan eğitim platformları (Zoom, Teamlink, Google Meet vb.) kolay bir şekilde kullanılabilir görüşünde mesleki kıdem değişkenine göre istatistiksel olarak anlamlı bir farkl111k bulunmuştur $(\chi 2=21.457, p=.001<.05)$. Siralar ortalamasına göre $1-5$ ve 6-10 kıdem grubundaki öğretmenlerin görüşlerinin 15 ve sonrası kıdem grubu öğretmen görüşlerine göre olumlu yönde anlamlı farklılık görülmüştür $\left(\mathrm{U}_{1-4}=-\right.$ 6.083; $\mathrm{U}_{2-4}=-3.666$ ). Katılımc1ların Uzaktan eğitim platformlarını (Zoom, Teamlink, Google Meet vb.) kullanmak için öğretmenlerin eğitim alması gerekir görüşünde mesleki kıdem değişkenine göre istatistiksel olarak anlamlı bir farklılık bulunmuştur $(\chi 2=15.507$, $\mathrm{p}=.001<.05)$. Siralar ortalamasına göre $1-5$ kıdem grubundaki öğretmenlerin görüşlerinin $15 \mathrm{ve}$ sonrası kıdem grubu öğretmen görüşlerine göre olumlu yönde anlamlı farklılık görülmüştür $\left(\mathrm{U}_{1-4}=-5.29\right)$. Katılımc1ların Uzaktan eğitimle bilgi birikimi kolay bir şekilde aktarlabilir görüşünde mesleki kıdem değişkenine göre istatistiksel olarak anlamlı bir farklılık bulunmuştur $(\chi 2=8.916, \mathrm{p}=.030<.05)$. Siralar ortalamasına göre $11-15 \mathrm{k} 1 \mathrm{dem}$ grubundaki öğretmenlerin görüşlerinin 1-5 k1dem grubu öğretmen görüşlerine göre olumlu yönde anlamlı farkl11ık görülmüştür $\left(\mathrm{U}_{1-3}=3.653\right)$. Kat1lımcıların uzaktan ĕgitim öğretmenler üzerinde ögrenme deneyimi sağlamaktadır görüşünde mesleki kıdem değişkenine göre istatistiksel olarak anlamlı bir farklılık bulunmuştur $(\chi 2=8.218, \mathrm{p}=.042<.05)$. Siralar ortalamasına göre 610 kıdem grubundaki öğretmenlerin görüşlerinin 1-5 kıdem grubu öğretmen görüşlerine göre olumlu yönde anlamlı farkl111k görülmüştür $\left(\mathrm{U}_{1-2}=3.672\right)$. Kat1lımc1ların uzaktan eğitimin her yerden ulaşılabilir olduğunu düşünüyorum görüşünde mesleki kidem değişkenine göre istatistiksel olarak anlamlı bir farkl1lı bulunmuştur $(\chi 2=14.514 \mathrm{p}=.002<.05)$. Siralar ortalamasına göre 6-10, 11-15 ile 15 ve sonrası kıdem grubundaki öğretmenlerin görüşlerinin 1-5 k1dem grubu öğretmen görüşlerine göre olumlu yönde anlamlı farkl1lık görülmüştür $\left(\mathrm{U}_{1-}\right.$ $\left.2=3.882 ; \mathrm{U}_{1-3}=4.528 ; \mathrm{U}_{1-4}=4.977\right)$. Kat1limc1ların uzaktan eğitim tek noktadan mobil uyum ile kolayca yönetim sağlar görüşünde mesleki kıdem değişkenine göre istatistiksel olarak anlamlı bir farkl111k bulunmuştur $(\chi 2=14.168, \mathrm{p}=.003<.05)$. Siralar ortalamasına göre 6-10 k1dem grubundaki öğretmenlerin görüşlerinin 1-5 kıdem grubu öğretmen görüşlerine göre olumlu yönde anlamlı farkl11ık görülmüştür $\left(\mathrm{U}_{1-3}=5.019\right)$. Kat1lımc1ların uzaktan eğitimle herkese uygun ögrenme yöntemi oluşturulabilir görüşünde mesleki kıdem değişkenine göre istatistiksel olarak anlamlı bir farklılık bulunmuştur $(\chi 2=9.774, \mathrm{p}=.021<.05)$. Siralar ortalamasına göre 610 kıdem grubundaki öğretmenlerin görüşlerinin 1-5 kıdem grubu öğretmen görüşlerine göre olumlu yönde anlamlı farklılık görülmüştür $\left(\mathrm{U}_{1-3}=3.85\right)$. Kat1lımcıların sinıf yönetiminin uzaktan eğitimde daha zor olduğunu düşünüyorum. görüşünde mesleki kıdem değişkenine göre istatistiksel olarak anlamlı bir farklıl1k bulunmuştur $(\chi 2=18.823 \mathrm{p}=.001<.05)$. Siralar ortalamasına göre 6-10 ve 11-15 kıdem grubundaki öğretmenlerin görüşlerinin 1-5 kıdem grubu öğretmen görüşlerine göre olumlu yönde anlamlı farkl1l1k görülmüştür $\left(\mathrm{U}_{1-2}=.896 ; \mathrm{U}_{1-}\right.$ $\left.3_{3}=1.064\right)$. Yine siralar ortalamasına göre 15 ve sonrası kıdem grubundaki öğretmenlerin görüşlerinin 6-10 kıdem grubu öğretmen görüşlerine göre olumlu yönde anlamlı farklılık görülmüştür $\left(\mathrm{U}_{3-4}=4.977\right)$. Katılımcıların uzaktan eğitim platformlarında çoğu zaman sıkıntı yaşanır görüşünde mesleki kıdem değişkenine göre istatistiksel olarak anlamlı bir farklılık bulunmuştur $(\chi 2=15.365, \mathrm{p}=.002<.05)$. Siralar ortalamasına göre $11-15$ ve sonras1 k1dem grubundaki öğretmenlerin görüşlerinin 1-5 k1dem grubu öğretmen görüşlerine göre olumlu yönde anlamlı farklılık görülmüştür $\left(\mathrm{U}_{1-3}=5.01 ; \mathrm{U}_{1-4}=4.13\right)$. Kat1lımcıların uzaktan eğitim ögretmenin iş yükünü artırır görüşünde mesleki kıdem değişkenine göre istatistiksel olarak anlamlı bir farkl11ık bulunmuştur $(\chi 2=11.674, \mathrm{p}=.009<.05)$. Siralar ortalamasına göre 11-15 
kıdem grubundaki öğretmenlerin görüşlerinin 1-5 kıdem grubu öğretmen görüşlerine göre olumlu yönde anlamlı farklılık görülmüştür $\left(\mathrm{U}_{1-3}=4.60\right)$.

Uzaktan eğitime ilişkin öğretmen görüş çalışmasında dördüncü alt probleme ait bulgulardan öğretmenlerin mesleki kıdem değişkenine göre görüşleri arasında anlamlı farklılık çıkan maddelere ilişkin bulgular Tablo 6'da gösterilmiştir.

Tablo 6. Görev Yeri Değişkenine Göre Kruskall Wallis H Testine Ait Bulgular

\begin{tabular}{|c|c|c|c|c|c|}
\hline Madde & Değişken & $x^{2}$ & df & $\mathbf{p}$ & $\mathbf{U}$ \\
\hline $\begin{array}{l}\text { 4. Uzaktan eğitimle bilgiye } \\
\text { kolayca ulaşılır. }\end{array}$ & $\begin{array}{l}\text { 1.Köy/Mahalle }(\mathrm{N}=50) \\
\text { 2. İlçe }(\mathrm{N}=119) \\
\text { 3. } \operatorname{Il}(\mathrm{N}=123)\end{array}$ & 6.7977 & 2 & .033 & $\begin{array}{l}1<2 \\
(\mathrm{U}=3.609)\end{array}$ \\
\hline $\begin{array}{l}\text { 12. Uzaktan eğitim } \\
\text { platformlarını (Zoom, } \\
\text { Teamlink, Google Meet vb.) } \\
\text { kullanmak için öğrencilerin } \\
\text { eğitim alması gerekir. }\end{array}$ & $\begin{array}{l}\text { 1.Köy/Mahalle }(\mathrm{N}=50) \\
\text { 2.İlçe }(\mathrm{N}=119) \\
\text { 3.İl }(\mathrm{N}=123)\end{array}$ & 10.6286 & 2 & .005 & $1>3(\mathrm{U}=4.55)$ \\
\hline $\begin{array}{l}\text { 13. Uzaktan eğitim } \\
\text { platformlarını (Zoom, } \\
\text { Teamlink, Google Meet vb.) } \\
\text { kullanmak için öğretmenlerin } \\
\text { eğitim alması gerekir }\end{array}$ & $\begin{array}{l}\text { 2. ̇̇lçe }(\mathrm{N}=119) \\
\text { 3.İl }(\mathrm{N}=123)\end{array}$ & 8.8590 & 2 & .012 & $\begin{array}{l}1>2 \\
(U=3.510) \\
1>3 \\
(U=4.123)\end{array}$ \\
\hline
\end{tabular}

Katılımcıların uzaktan eğitimde bilgiye kolayca ulaşılır görüşünde görev yeri değişkenine göre istatistiksel olarak anlamlı bir farkl1lık bulunmuştur $(\chi 2=6,7977 \mathrm{p}=.033<.05)$. Siralar ortalamasına göre ilçede görev yapan öğretmenlerin görüşlerinin köy/mahallede görev yapan öğretmen görüşlerine göre olumlu yönde anlamlı farklılık görülmüştür $(\mathrm{U}=3.609)$. Katılımcıların Uzaktan eğitim platformlarını (Zoom, Teamlink, Google Meet vb.) kullanmak için öğrencilerin eğitim alması gerekir görüşünde mesleki kıdem değişkenine göre istatistiksel olarak anlamlı bir farkl111k bulunmuştur $(\chi 2=10.6286, \mathrm{p}=.005<.05)$. Sıralar ortalamasına göre köy/mahallede görev yapan öğretmenlerin görüşlerinin ilde görev yapan öğretmen görüşlerine göre olumlu yönde anlamlı farklılık görülmüsstür ( $\mathrm{U}=4.55)$. Kat1lımcıların Uzaktan eğitim platformlarını (Zoom, Teamlink, Google Meet vb.) kullanmak için ögretmenlerin eğitim alması gerekir görüşünde mesleki kıdem değişkenine göre istatistiksel olarak anlamlı bir farklılık bulunmuştur $(\chi 2=8.8590, p=.012<.05)$. Sıralar ortalamasına göre köy/mahallede görev yapan öğretmenlerin görüşlerinin hem ilde görev yapan öğretmen görüşlerine göre $(U=4.123)$ hem de ilçede görev yapan öğretmen görüsslerine göre olumlu yönde anlamlı farklılık görülmüştür $(\mathrm{U}=3.510)$.

Uzaktan eğitime ilişkin öğretmen görüş çalışmasında beşinci alt probleme ait bulgulardan ögretmenlerin uzaktan eğitimle ders verme değişkenine göre görüşleri arasında anlamlı farklılık çıkan maddelere ilişkin bulgular Tablo 7'de gösterilmiştir.

Tablo 7. Ders Verme Değişkenine Göre Mann Whitney U Testi Bulaguları

\begin{tabular}{|c|c|c|c|c|}
\hline Madde & Değişken & $\mathrm{p}$ & $\mathrm{U}$ & $\mathrm{r}$ \\
\hline 11. Uzaktan eğitim platformları (Zoom, Google Meet & Evet $(\mathrm{N}=256)$ & 027 & 2650 & 21 \\
\hline vb.) kolay bir şekilde kullanılabilir. & Hayır $(\mathrm{N}=36)$ & .032 & 3052 & .21 \\
\hline 12. Uzaktan eğitim platformlarını (Zoom, Google & $\operatorname{Evet}(\mathrm{N}=256)$ & & & \\
\hline $\begin{array}{l}\text { Meet vb.) kullanmak için öğrencilerin eğitim alması } \\
\text { gerekir. }\end{array}$ & Hayır $(\mathrm{N}=36)$ & .013 & 3481 & .24 \\
\hline $\begin{array}{l}\text { 22. Uzaktan eğitim tek noktadan mobil uyum ile } \\
\text { kolayca yönetim sağlar. }\end{array}$ & $\begin{array}{l}\text { Evet }(\mathrm{N}=256) \\
\text { Hayır }(\mathrm{N}=36)\end{array}$ & .039 & 3670 & .20 \\
\hline
\end{tabular}


Katılımcıların uzaktan eğitim platformları (Zoom, Google Meet vb.) kolay bir şekilde kullanılmasına yönelik görüşlerinde uzaktan eğitimle ders verme değişkenine göre ders veren öğretmenler $(\bar{X}=3.61)$ ile ders vermeyen öğretmenler $(\bar{X}=3.17)$ arasında uzaktan eğitimle ders verenlerin lehine yönelik istatiksel olarak anlamlı farklılık bulunmuştur ( $U=3652$, $\mathrm{p}=.032<.05$ ). Katılımcıların uzaktan eğitim platformlarını (Zoom, Google Meet vb.) kullanmak için öğrencilerin eğitim alması gerektiğine yönelik görüşlerinde uzaktan eğitimle ders verme değişkenine göre ders veren öğretmenler $(\bar{X}=3.29)$ ile ders vermeyen öğretmenler $(\bar{X}=3.72)$ arasında uzaktan eğitimle ders vermeyenlerin lehine yönelik istatiksel olarak anlamlı farklılık bulunmuştur $(\mathrm{U}=3481, \mathrm{p}=.013<.05)$. Katılımcıların uzaktan eğitim tek noktadan mobil uyum ile kolayca yönetim sağlamasına yönelik görüşlerinde uzaktan eğitimle ders verme değişkenine göre ders veren öğretmenler $(\bar{X}=2.93)$ ile ders vermeyen öğretmenler $(\bar{X}=2.53)$ arasında uzaktan eğitimle ders verenlerin lehine yönelik istatiksel olarak anlamlı farklılık bulunmuştur $(\mathrm{U}=3670, \mathrm{p}=.039<.05)$. Katılımcıların zaman esnekliği bakımından yüz yüze eğitime göre daha avantajlı olmasına yönelik görüşlerinde uzaktan eğitimle ders verme değişkenine göre ders veren öğretmenler $(\overline{\mathrm{X}}=3.18)$ ile ders vermeyen öğretmenler $(\overline{\mathrm{X}}=2.36)$ arasında uzaktan eğitimle ders verenlerin lehine yönelik istatiksel olarak anlamlı farklllık bulunmuştur $(\mathrm{U}=2946, \mathrm{p}=.001<.05)$. Katılımcıların Sinıf yönetiminin uzaktan eğitimde daha zor olduğuna yönelik görüşlerinde uzaktan eğitimle ders verme değişkenine göre ders veren öğretmenler $(\bar{X}=3.51)$ ile ders vermeyen öğretmenler $(\bar{X}=3.94)$ arasında uzaktan eğitimle ders verenlerin lehine yönelik istatiksel olarak anlamlı farkl11ık bulunmuştur $(U=3676, p=.043<.05)$.

Uzaktan eğitime ilişkin öğretmen görüş çalışmasında altıncı alt probleme ait bulgulardan öğretmenlerin COVID-19 öncesi uzaktan eğitimle ders verme değişkenine göre görüşleri arasında anlamlı farklılık çıkan maddelere ilişkin bulgular Tablo 8' de gösterilmiştir.

Tablo 8. COVID-19 Öncesi Ders Verme Değişkenine Göre Mann Whitney U Testine Ait Bulgular

\begin{tabular}{lllll}
\hline Madde & Değişken & $\mathrm{p}$ & $\mathrm{U}$ & $\mathrm{r}$ \\
\hline $\begin{array}{l}\text { 26. Akademik başarı, yüz yüze eğitimde uzaktan } \\
\text { eğitime göre daha iyidir. }\end{array}$ & $\begin{array}{l}\text { Evet }(\mathrm{N}=12) \\
\text { Hayır }(\mathrm{N}=280)\end{array}$ & .010 & 981 & .42 \\
\hline
\end{tabular}

Tablo 8'de görüldüğg̈ gibi öğretmenlerin akademik başarı, yüz yüze eğitimde uzaktan eğitime göre daha iyidir görüşüne yönelik COVID-19 öncesi uzaktan eğitimle ders veren öğretmenlerin $(\overline{\mathrm{X}}=2.67)$ ile ders vermeyen öğretmenler $(\overline{\mathrm{X}}=3.81)$ arasında COVID-19 öncesi uzaktan eğitimle ders vermeyen öğretmenler lehine istatiksel olarak anlamlı bir farklılık bulunmuştur ( $\mathrm{U}=981, \mathrm{p}=.010<.05)$. Uzaktan eğitime ilişkin öğretmen görüş çalışmasında altınc1 alt probleme ait nitel bulgular temalar ve kategoriler haline getirilerek grafik ve şekiller şeklinde gösterilmiştir. Uzaktan eğitimin avantajları ve dezavantajlarına ilişkin öğretmen görüşlerine ilişkin bulgular Grafik 1'de gösterilmiştir. 


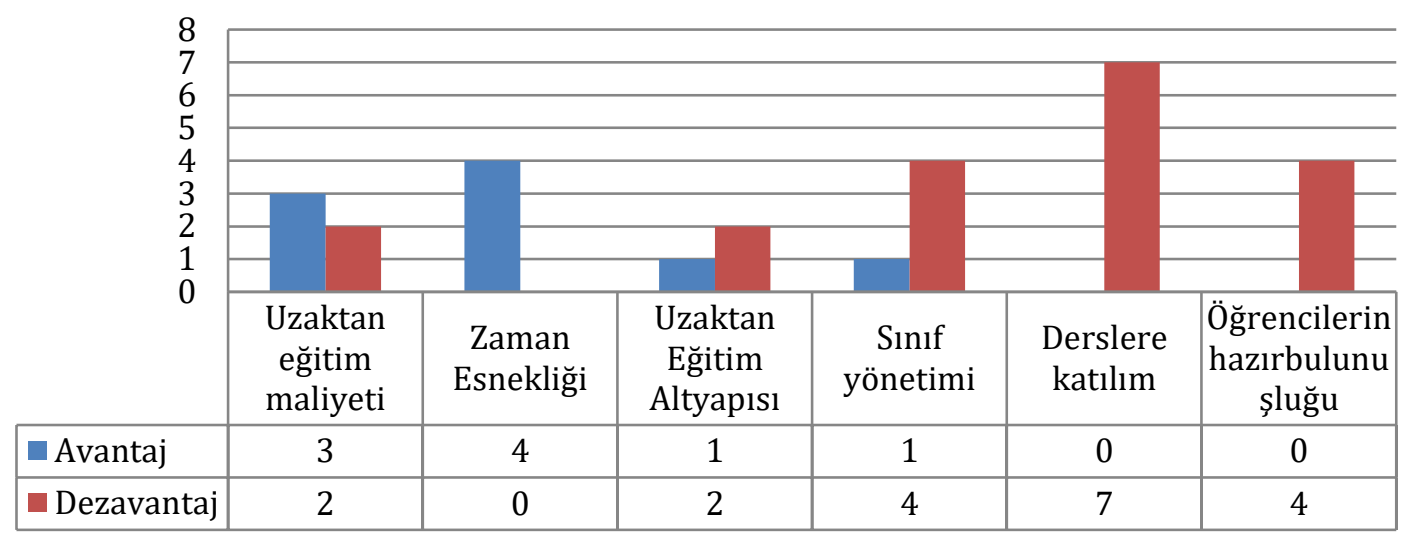

Grafik 1.Uzaktan Eğitimin Avantajları ve Dezavantajları

Grafik 1'de görüldüğü gibi katılımcılar zaman esnekliği $(f=4)$ uzaktan eğitimin avantaj1 olarak görmektedir. Uzaktan eğitime öğrencilerin hazırbulunuşluğu $(f=4)$ ve öğrencilerin katılımını ya da devamsızlı durumunun $(f=7)$ dezavantajları arasında olduğunu belirtmişlerdir. Alt yapı, maliyet konularını hem avantaj hem de dezavantaj olarak görmüşlerdir. Sınıf yönetimi konusu ise uzaktan eğitimin dezavantajları $(f=4)$ görüşünde yoğunlaşmaktadır. Katılımcıların konuyla ilgili görüşlerinin bazıları şu şekildedir:

"Maliyet açısından yüz yüze eğitime istinaden daha düşük bir maliyet sağladı̆g için avantajlıdır. Zamanda esneklik uzaktan eğitimin en büyük avantajlarından biridir. Uzaktan eğitimdeki sinırl saatlerden ziyade uzaktan eğitimde zaman ayarlaması daha esnektir. Her öğrenci evinde, yaşadiğ çevrede yeterli ve düzgün alt yaplya sahip olmadiğı için uzaktan ĕgitim bu yönden dezavantaja sahiptir. Her ögrrenciye ulaşılamadığı için katılımda sorunlar yaşanıyor. Öğretmen sınıf yönetiminde aynı anda birçok sesin yükselmesi, her ögrrenciye ulaşılamama, devamsızlık gibi problemlerde dezavantaj yaşanabilir..." (Ö7).

"... katılım düzeyi bazı bölgelerde imkansızlı nedeniyle bazı bölgelerde düşüktür. Ayrıca sinıf ortamı ve atmosferi olmama nedeniyle dezavantajdır..." (Ö8).

Uzaktan eğitimin okul yönetimi temasına yönelik öğretmen görüşlerine ilişkin bulgular Şekil 1'de gösterilmiştir.

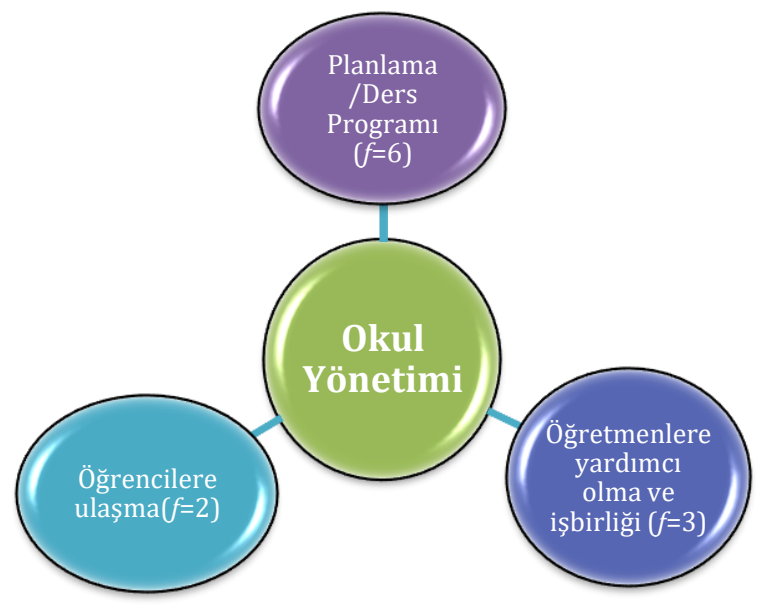

Şekil 1. Uzaktan Eğitimde Okul Yönetimine İlişkin Bulgular 
Şekil 1'de görüldüğü gibi katılımcılar uzaktan eğitimde okul yönetiminin rollerine yönelik ders plan ve programı $(f=6)$, öğretmenlere yardımcı olma ve işbirliği yapma $(f=3)$ ve öğrencilere ulaşma $(f=2)$ konusunda destek verdikleri görüşündedirler. Katılımcıların konuyla ilgili görüşlerinin bazıları şu şekildedir:

"...evet, uzaktan eğitim sürecini planlayarak verimli bir eğitim süreci devam etmesini sağlamıştır... " (Ö1).

"...okul idaresi uzaktan eğitimi planlama, saatlerdeki uygunluk, öğrencilere ulaşma konusunda ve öğretmenlerle işbirliği yaparak uzaktan ĕgitim faaliyetlerini yoğun bir şekilde sürdürmektedir..." (Ö7).

Uzaktan eğitimin hangi alanlarda uygulanabilirliği temasına yönelik öğretmen görüşlerine ilişkin bulgular Şekil 2'de gösterilmiştir.

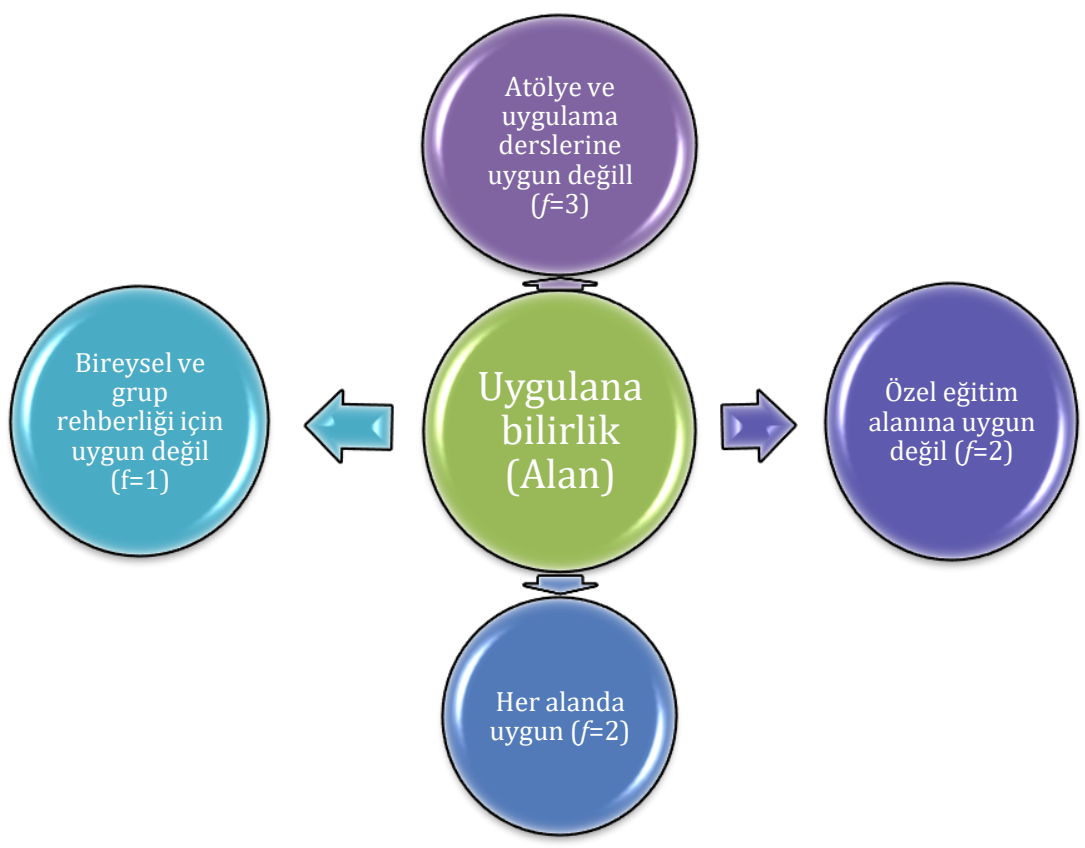

Şekil 2. Uzaktan Eğitimin Uygulanabilirliğine (Alan) İlişkin Bulgular

Şekil 2'de görüldüğü gibi katılımcıların uzaktan eğitimin her alanda uygulanabilirliği konusunda sinırlı sayı da uygun olduğu görüșündedir $(f=2)$. Bu görüşün aksine uzaktan eğitimin atölye ve uygulama $(f=3)$, özel eğitim $(f=2)$ ve bireysel ve grup psikolojik danışmanlık ve rehberlik $(f=1)$ alanlarında uygun olmadığ görüşünde olan katılımcılarda bulunmaktadır. Katılımcıların konuyla ilgili görüşlerinin bazıları şu şekildedir:

"...hayır, uzaktan eğitim sanal ortamda olduğu için atölye derslerine uygun olmadiğını düşünüyorum. Özel eğitim öğrencileri ile gerektiği yerde temas kurulmasl gerektiği için özel eğitim açısından da bir dezavantaj olduğunu düşünüyorum ..." (Ö1).

"...uzaktan eğitimin her alanda kullanılabileceğini düşünüyorum. Çünkü maliyet, zaman açısından oldukça tasarruflu bir yöntem ..." (Ö3).

"...hayır uygulama gerektiren ders içeriklerinde yetersiz kalabilir..." (Ö6).

"...her alanda uygulanabileceğini düşünmüyorum. Özellikle benim branşım için pek uygun değil. Sinıf rehberliği, seminer konuları verilebilir fakat bireysel psikolojik danışma ve grupla psikolojik danışma konuları maalesef yapılamıyor. Çünkü sağlıklı terapatik ortam sağlanamıyor..." (Ö8). 
Uzaktan eğitimin hangi kademelerde uygulanabilirliği temasına yönelik öğretmen görüşlerine ilişkin bulgular Şekil 3'te gösterilmiştir.

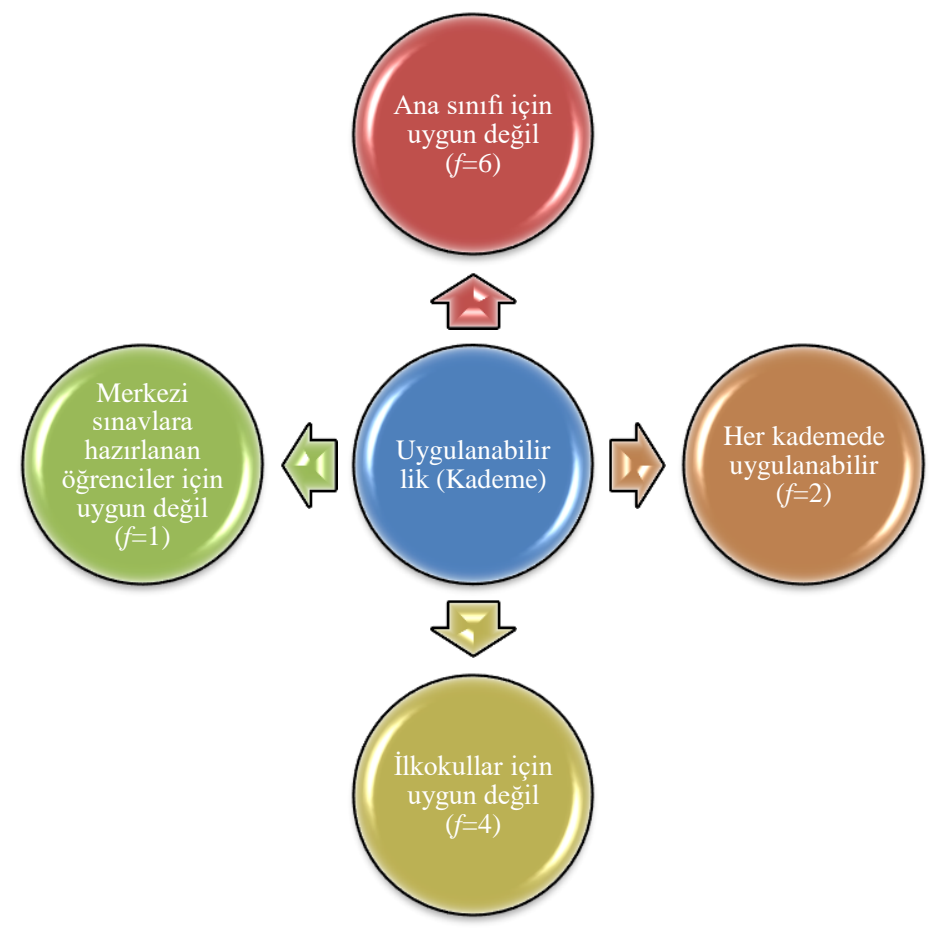

Şekil 3. Uzaktan Eğitimin Uygulanabilirliğine (Kademe) İlişkin Bulgular

Şekil 3'te görüldüğ ü gibi katılımcılar ana sınıfı $(\mathrm{f}=7)$ ve ilkokullar $(\mathrm{f}=4)$ için uzaktan eğitimin uygun olmadığı görüşündedirler. Yine sınava hazırlanan öğrenciler $(\mathrm{f}=1)$ uygun olmadığı görüşüne olanlarda mevcuttur. Ancak sınırlı sayıda uzaktan eğitimin her kademede uygulanabileceği ( $\mathrm{f}=2$ ) görüşünde olan katılımcılarda mevcuttur. Katılımcıların konuyla ilgili görüşlerinin bazıları şu şekildedir:

"...hayır, düşünmüyorum. Ana slnıfi ve özel eğitimde ögrrenci ile birebir temas kurulmadan tam anlamılla bir eğitim olmayacaktır..." (Ö1).

"...her kademede verimli olacağını düşünmüyorum ..." (Ö2).

"...anasinifi, ilkokul ve sinav senesi olan 8. ve 12. siniflarda uzaktan eğitimden ziyade yüz yüze olmal. Ama uzaktan eğitimle desteklenmeli..." (Ö4).

"...hayır düşünmüyorum. Zorunlu oldukça ortaokul ya da lisede uygulanabilir..." (Ö7).

Uzaktan eğitimin teknoloji ve teknolojik altyapı temasına yönelik öğretmen görüşlerine ilişkin bulgular Şekil 4'te gösterilmiştir. 


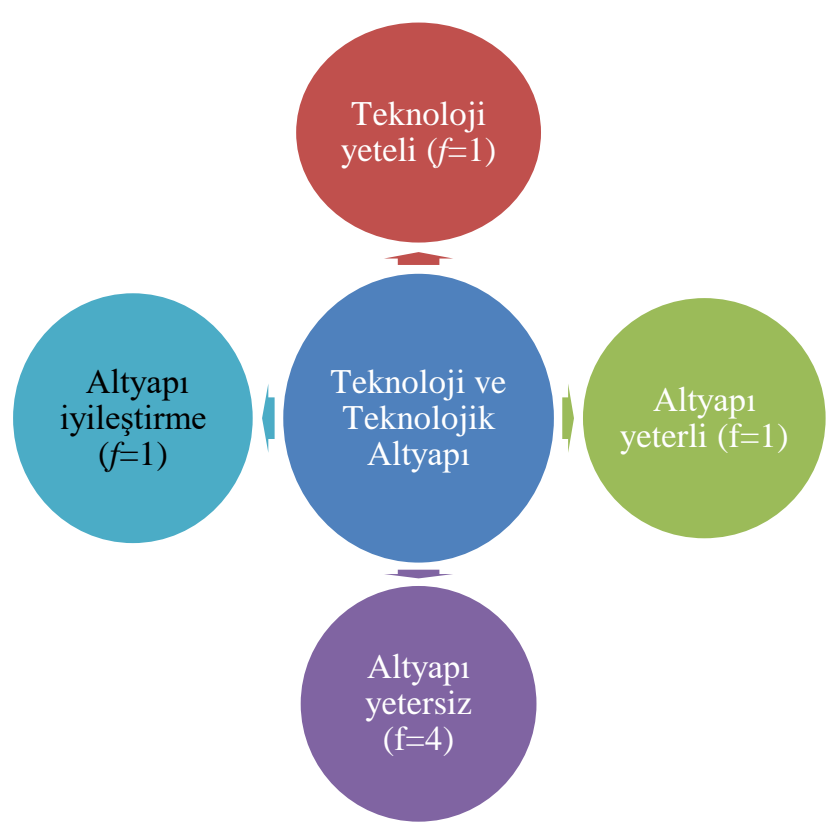

Şekil 4. Uzaktan Eğitimde Teknoloji ve Teknolojik Altyapıya İlişkin Bulgular

Şekil 4'te görüldüğü gibi katılımcılar uzaktan eğitim için altyapının yetersiz $(f=4)$ olduğu görüşündedirler. Ancak uzaktan eğitim için yeterli teknoloji $(f=1)$ olduğu ve COVID19 süreci ile altyapının iyileştiği $(f=1)$ görüşünde olan katılımcılarda mevcuttur. Bunun yanı sıra altyapının yeterli $(f=1)$ olduğu görüşünde olanda mevcuttur. Katılımcıların konuyla ilgili görüşlerinin bazıları şu şekildedir:

"...teknoloji yeterli teknolojik alt yapı yetersiz..." (Ö1).

"...zaman zaman aksaklıklar yaşansa da genel olarak teknolojik alt yapının yeterli olduğunu düşünüyorum..." (Ö3).

"...sürecin başında yetersizdi. Sürecin devamında iyileştirildi..." (Ö5).

"...yeterli olmadığını düşünmekteyim..." (Ö6).

"...köy ve kırsal yerleşim yerlerinde yaşayan ögrencilerin teknolojik alt yapıya sahip olmada sıkıntı yaşadı̆̆ görülmüştür ve maddi durum yetersizliği nedeniyle teknolojik aletlere erişsimde yaşadığı sıkıntılar da maalesef mevcuttur..." (Ö7).

"... uzaktan ĕgitimin yeni başladı̆̆ zamanlar teknolojik alt yapının yetersizliği nedeniyle ders yaparken çok fazla zorluk çektik. Şuan da zaman zaman zorluklar yaşasak da iyileştirme ve geliştirme yapıldığının farkındayım..." (Ö8).

Uzaktan eğitimin eğitimde fursat eşitliği temasına yönelik öğretmen görüşlerine ilişkin bulgular Şekil 5'te gösterilmiştir. 


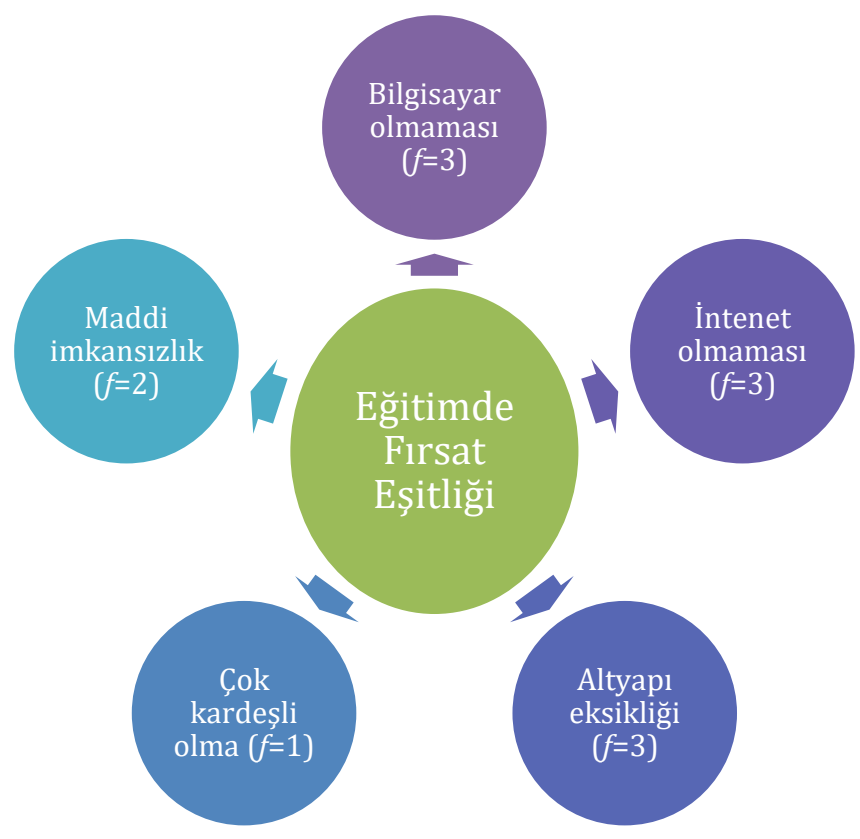

Şekil 5. Uzaktan Eğitimde Fırsat Eşitliğine İlişskin Bulgular

Şekil 5'te görüldüğü gibi katılımcılar uzaktan eğitim sürecinin internet olmaması $(f=3)$, bilgisayar olmaması $(f=3)$, altyapı yetersizliği $(f=3)$, maddi imkânsızlıklar $(f=3)$ ve çok kardeşli $(f=1)$, olmaktan dolayı firsat eşitliğini sağlamadığını düşünmektedirler. Katılımcıların konuyla ilgili görüşlerinin bazıları şu şekildedir:

"...Hayır karşılamamaktadır. Interneti ve bilgisayarı olmazsa öğrenciler bu eğitimden yararlanamayacaktır..." (Ö1).

"...kesinlikle karşılamıyor. Interneti olmayan bir sürü ögrenci var, dersleri takip edemiyor..." (Ö2).

"...tam olarak karşıladiğı kanaatinde değilim. Çünkü bütün öğrencilerin maddi olarak uzaktan eğitim için gerekli materyallere sahip olmadı̆̆ını düşündüğüm için firsat eşitliği ilkesini tam olarak karşılamıyor..." (Ö3).

"...kesinlikle karşılamamaktadır. Çoğu ögrrenci imkânsızlıklar nedeniyle uzaktan eğitime katılamamaktadir. Bu da firsat eşitliğini engeller"(Ö4).

"...yapılan bu uygulamanın var olan eşitsizliği daha da derinleştirdiğini düşünüyorum ..." (Ö5).

Uzaktan eğitimin sağlığa zararları temasına yönelik öğretmen görüşlerine ilişkin bulgular Şekil 6' da gösterilmiştir. 


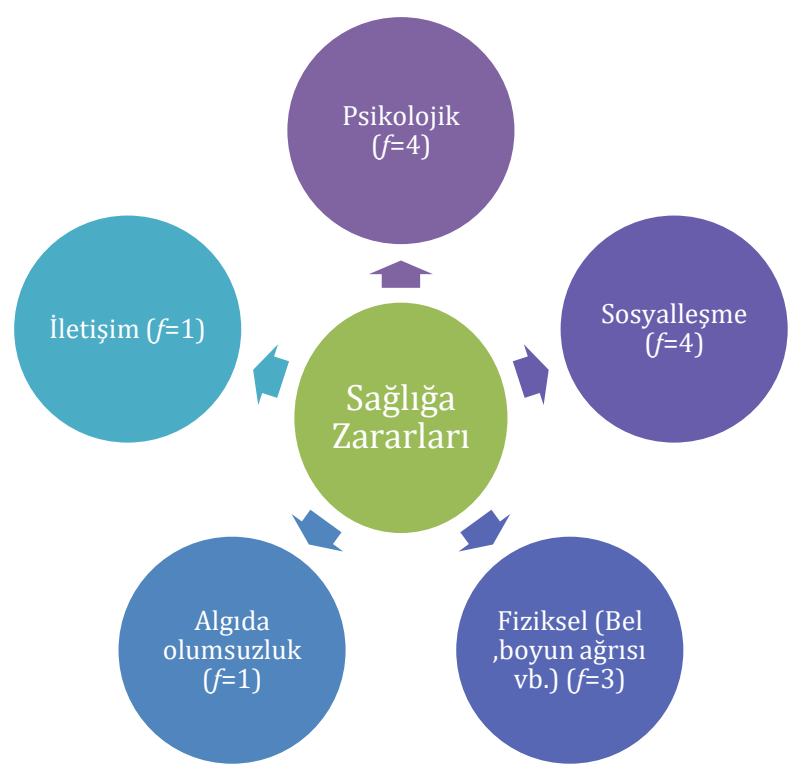

Şekil 6. Uzaktan Eğitimin Zararlarına İlişkin Bulgular

Şekil 6'da görüldüğü gibi katılımcılar uzaktan eğitimin öğrencilerde psikolojik $(f=4)$, sosyalleşme $(f=4)$, fiziksel rahatsızlıklar/bel, baş ve boyun ağrısı vb.) $(f=3)$, algıda olumsuzluk $(f=1)$ ve iletişim $(f=1)$ problemlerinin oluşturduğu görüşündedirler. Katılımciların konuyla ilgili görüşlerinin bazıları şu şekildedir:

"...duruş bozukluğuna, bel, boyun, omuz ağrllarına yol açıyor. Sosyalleşmeye engel oluyor. Insanların kalpleri birbirinden uzaklaşıyor. Uzun süre bir ekrana bakma algıyı olumsuz etkiliyor olabilir." (Ö2).

"...gereğinden fazla kullanıldığında zararlı olabileceğini düşünüyorum. Göz ve boyun sağlığına zarar verdiğini düşünüyorum. Kendini iyi ifade edemeyen çocukların yetişmesi ile iletişime kapalı toplum oluşabilir. Psikolojik olarak asosyal bireyler yetişebilir." (Ö8).

\section{TARTIŞMA, SONUÇ VE ÖNERILLER}

Çalışmada katılımcılar öğrenmede karşılaşılan güçlüklerin uzaktan eğitimle çözülmesinin daha kolay olduğu görüşünü olumsuz karşılamışlardır. Gerekçe olarak öğretmenler uzaktan eğitimin her alanda ve kademede uygulanamayacağını belirtmişlerdir. $\mathrm{Bu}$ duruma benzer şekilde uzaktan eğitimde uygulama derslerinin sağlıklı işlenmediğine ilişkin sonuçlarda mevcuttur (Almuraqap, 2020; Utomo, 2020). Nitekim uzaktan eğitimde öğrenme güçlüklerinin çözülebilmesi için sınıf yönetiminde etkili iletişimin olması gerektiği belirtilmektedir ki yapılan araştırmalarda öğretmen öğrenci arasındaki iletişim uzaktan eğitimin dezavantajları arasında olduğu görülmüştür (Özdoğan ve Berkant, 2020). Ancak Horspol ve Lange (2012) çalışmalarında uzaktan eğitimin çevrimiçi ortamda etkili iletişim ve öğrenme kolaylığı sağladığını ve uzaktan eğitimin bu durumlar için avantaj olduğu sonucuna ulaşmışlardır. Katılımcılar uzaktan eğitimin öğrencilere firsat eşitliği sağlamadığını düşünmektedirler. Benzer sonuçlar literatürde mevcuttur (Karacaoğlu ve diğerleri, 2021 ). Çalışmada katılımcılar bu durumun gerekçesini her öğrencide internet ve bilgisayar olmamasına veya maddi imkânsızlıklarına bağlamaktadırlar. Benzer şekilde Yılmaz, Güner, Mutlu ve Arın Yılmaz, (2020) çalışmalarında MEB'in uzaktan eğitimde firsat ve eşitliği sağlamak için gerekli materyalleri sağlaması gerektiği belirtmiştir. Nitekim literatürde yapılan araştırmalar incelendiğinde benzer sonuçlar mevcuttur (Ramos-Morcillo, Leal Costa, Moral García ve Ruzafa Martínez, 2020; Özdoğan ve Berkant, 2020). Katılımcılar uzaktan eğitim 
aracılığıyla daha geniş kitlelere ulaşılmadığını düşünmektedirler. Bu duruma öğrencinin uzaktan eğitim için gerekli altyapıya maddi imkânsızlıklar nedeniyle sahip olmamasını gerekçe göstermektedirler. Çalışmada katılımcılar uzaktan eğitimin her kademedeki öğrenciye uygulanamayacağını belirtmişlerdir. Katılımcılar gerekçe olarak ana sınıfı ve ilkokul öğrencilerin bilişsel ve duyuşsal yönden hazır olmamalarını, sosyalleşme ve akran eğitiminden eksik kaldıklarını, sınavlara hazırlanan öğrenciler için ise yeterli sürenin olmamasını göstermişlerdir. Katılımcılar uzaktan eğitimin her yerden ulaşılabileceği görüşüne katılmamaktadırlar. Gerekçe olarak maddi imkânsızlıklar ve kırsal kesimdeki internet alt yapı eksikliklerini göstermişlerdir. Konuyla ilgili olarak mesleki kıdemi az olan öğretmenlerin diğer altı yılın üzerindeki mesleki kıdeme sahip öğretmenlere göre görüşlerinde olumsuz yönde anlamlı farklılık olduğu sonucuna ulaşılmıştır. Katılımcılar genel olarak uzaktan eğitimle ilgili herkese uygun yöntem geliştirilemeyeceğini düşünmemektedirler. Öğretmenler gerekçe olarak ana sınıfı ve ilkokul öğrencilerinin bilişsel ve duyuşsal yönden uzaktan eğitim için hazır bulunmadıklarını belirtmişlerdir . Ancak bu konuda erkek öğretmenlerin kadın öğretmenlere göre görüsşlerinde olumlu yönde anlamlı farklılık görülmüştür. Konuyla ilgili mesleki kıdemi 6-10 yıl olan öğretmenlerin 1-5 yıl olan öğretmenlere göre görüşlerinde olumlu yönde anlamlı farklılık olduğu görülmüş̧ür. Katılımcılar uzaktan eğitimle bilgiye daha kolay ulaşılabileceği konusunda kısmi olarak katıldıkları görülmüştür . Konuyla ilgili mesleki kıdemi 11-15 yıl olan öğretmelerin mesleki kıdemi 1-5 yıl olan öğretmenlere göre görüşlerinin olumlu yönde anlamlı farklılık gösterdiği görülmüştür. Yine görev yeri ilçe merkezi olan öğretmenlerin köy/mahalle olan öğretmenlere göre görüşlerinde olumlu yönde anlamlı farklılık gösterdiği görülmüştür. Katılımcıların bu duruma kısmi olarak katılma gerekçesi uzaktan eğitimin zaman yönetimi konusunda esnek olması ve yeterli alt yap1 olduğu takdirde kitaptan daha kolay ulaşılabilmesidir.

Katılımcılar uzaktan eğitimle bilgiye daha hızlı ulaşılabileceği konusunda da kısmi olarak destekleme nedeni farklı mekânda öğretmen ve öğrencilerin istediği zamanda görüşebilmelerini göstermektedirler. Nitekim bu gerekçe uzaktan eğitimi tanımında da yer almaktadır (Valentıne, 2002). Katılımcılar okul ortamına ihtiyaç olmadan eğitim alma firsatına da kısmen katılım göstermişlerdir. Bu durumun dezavantaj olan kısmı öğrencilerin sosyalleşme ve akran eğitimi gibi konularda eksik kalmasından kaynaklanmasıdır (Karacaoğlu ve diğerleri, 2021; Keskin ve Özer Kaya, 2020). Avantajlı yönü ise öğrencilerin derslerden geri kalmaması ve zamandan bağımsız olmasıdır (Özdoğan ve Berkant, 2020). Yine uzaktan eğitim ders videolarının tekrar tekrar izlenebilmesidir (Yolcu, 2020). Katılımcılar öğrencilerin ve öğretmenlerin uzaktan eğitimde kullanılan platformlar hakkında eğitim almalarına ilişkin görüşleri genel olarak olumlu olsa da katılımcıların uzaktan eğitimle ders verme, görev yeri ve mesleki k1deme göre görüşlerinde anlamlı farklılıklar görülmektedir. Köy/mahallede çalışan öğretmenler il ve ilçe merkezinde çalışan öğretmenlere göre öğrencilerin ve öğretmenlerin eğitim almaları gerektiğini belirtmişlerdir. Yine mesleki kıdemi az olan öğretmenlerde kıdem y1lı fazla olan öğretmenlere göre öğrenci ve öğretmenlerin eğitim alması gerektiğini vurgulamışlardır. Yine uzaktan eğitimle ders vermeyen öğretmenlerde ders veren öğretmenlere göre eğitim alınması gerektiğini vurgulamıştır. Nitekim Andoh, Appiah ve Agyei (2020) uzaktan eğitimde teknolojik imkânların daha etkin kullanılması gerektiğini belirtmiştir. Katılımcılar öğretmenlerin bilgi birikimini kolay bir şekilde aktarabileceğine kısmen katılmaktadırlar. Nitekim katılımcılar uzaktan eğitimin atölye ve uygulamalı alanlarda sınırlı kaldığını belirtmişlerdir.Benzer şekilde Kan ve Fidan (2016) çalışmalarında uzaktan eğitimde deslerin teorik bilgi temelli yürütüldüğünü ve bu durumun uzaktan eğitimin sinırlılığ olduğunu belrtmişlerdir. Çalışma kapsamında bilginin uzaktan eğitimle daha kolay aktarılacağına yönelik erkek öğretmenler kadın öğretmenlere göre daha olumlu bir görüş sergilemişlerdir. Yine mesleki kıdemi 11-15 yıl olan öğretmenler 1-5 yıl olan öğretmenlere göre daha olumlu görüş sergilemişlerdir. Katılımcılar uzaktan eğitim uygulamalarının öğrenciler üzerinde deneyim sağladığı görüşüne kısmen katılsa da öğretmenlerin farklı öğretme metotları kazandığı görüşüne katılmaktadırlar. Öğretmenler üzerinde öğrenme 
deneyimi sağladığına yönelik mesleki kıdemi 6-10 y1l olan öğretmenler 1-5 y1l olan öğretmenlere göre daha olumlu görüş sergilemişlerdir. Katılımcılar uzaktan eğitimin daha düşük maliyetle sağlandığı görüşüne kısmen katılmaktadırlar. Uzaktan eğitimin daha düşük maliyetle sağlandığ görüşüne erkek öğretmenler daha olumlu bir görüş sergilediği sonucuna ulaşılmıştır. Nitekim öğretmenler uzaktan eğitim için gerekli teknolojik altyapının yetersiz olduğunu ve velilerin öğrencilerin uzaktan eğitim için gerekli olan internet ve bilgisayar vb. materyalleri tedarik edemediğini belirtmişlerdir. Türker ve Dündar (2020) bu durumu destekler nitelikte uzaktan teknolojik ve altyapı eksikliğinin uzaktan eğitimin engelleri arasında olduğunu söylemiştir. Nitekim çalışmada katılımcılarla yapılan görüşmede uzaktan eğitimin maliyet yönünden avantajlı olduğu görüşünü kısmi olarak desteklemişlerdir. Katılımcılar uzaktan eğitimin tek bir noktadan mobil uyum ile kolay bir şekilde yönetimine kısmen katılmaktadırlar. Bu konuda erkek öğretmenler kadın öğretmenlere göre daha olumlu görüş sergilemişlerdir. Yine 6-10 yıl mesleki kıdeme sahip öğretmenler 1-5 yıl mesleki kıdeme sahip ögretmenlere göre daha olumlu görüş sergilemektedirler. Uzaktan eğitimle ders veren öğretmenlerinde ders vermeyen öğretmenlere göre daha olumlu görüş sergiledikleri görülmüştür. Ancak mekân yönünden farklı ortamlarda bulunulduğundan dolayı yönetimin kolay bir şekilde sağlanamayacağı açıktır. Katılımcılar uzaktan eğitim zaman esnekliği bakımından avantaj olduğu görüşüne kısmen katılmaktadır. Konuyla ilgili uzaktan eğitimle ders veren öğretmenlerin ders vermeyen öğretmenlere göre daha olumlu görüş sergiledikleri görülmüştür. Nitekim uzaktan eğitim platformlarının yoğunluktan dolayı kilitlediği durumlar yaşanmıştır.

Katılımcılar öğretmenlerin uzaktan eğitim platformlarını kolay bir şekilde kullandığını ancak bu konuda öğretmenlerin eğitim alması gerektiğini belirtmişlerdir. Konuyla ilgili uzaktan eğitim ile ilgili ders veren öğretmenler ile vermeyen öğretmenler arasında ders verenlerin lehine anlamlı farklılık çıkmıştır. Katılımcılar öğretmenlerin her dersten (alandan) uzaktan eğitimle ders verilemeyeceğini belirtmişlerdir. Katılımcılar gerekçesini sunarken branşlarına göre farklılaşsa da genel olarak özel eğitim öğrencilerine uygun olmadı̆̆ı, atölye dersleri için uygun olmadığı, uygulamalı (beden eğitimi, müzik vb.) dersler için uygun olmadığı görüşünü belirtmişlerdir. Katılımcılar uzaktan eğitimin günümüz koşullarında zorunlu hale geldiğini belirtmişlerdir. Nitekim bu durumun nedeni şüphesiz COVID-19 salgın sürecidir. Katılımcılar uzaktan eğitim sürecinin öğretmenlere farklı öğretme metotları deneyimi sağladığı görüşünedirler (Tablo 4). Katılımcılar uzaktan eğitimde sınıf yönetiminin yüz yüze eğitime göre daha zor olduğunu düşünmektedirler. Konuyla ilgili mesleki kıdemi 1-5 y1l olan öğretmenler 6-10 yıl ve 11-15 yıl olanlara göre daha olumlu görüş sergilemektedirler. Yine mesleki yılı 15 yıldan fazla olan öğretmeneler de 11-15 yıl mesleki k1deme sahip olan öğretmenlere göre olumlu görüş sergilemişlerdir. Yine konuyla ilgili olarak uzaktan eğitimle ders vermeyen öğretmenlerin ders veren öğretmenlere göre daha olumlu görüş sergiledikleri görülmüsstür. Katılımcılar akademik başarını yüz yüze eğitimde daha iyi olduğunu belirtmişlerdir. Konuyla ilgili COVID-19 salgını öncesinde uzaktan eğitimle ders vermeyen öğretmenlerin ders verenlere göre daha olumlu görüş sergiledikleri görülmüştür. Katılımcılar uzaktan eğitim platformlarında sıkıntılar yaşandığını belirtmişlerdir. Gerekçesini özellikle kırsal kesimlerde yaşanan uzaktan eğitim teknolojik altyapı ve internet erişimi ile ilgili sıkıntıları göstermişlerdir. Literatürde altyapı ve erişim sorunlarının uzaktan eğitimin en önemli problemi olduğu sonucuna ulaşan çalışmalar mevcuttur (Akgül, 2021 ; Özdemir Baki ve Çelik,2021; Sarı ve Nayır, 2020) Yine mesleki kıdemi az olan öğretmenler fazla mesleki kıdeme sahip öğretmenlere göre uzaktan eğitim platformlarında daha çok sıkıntı yaşadıklarını belirtmişlerdir. Nitekim Türker ve Dündar (2020) lise öğretmenleri ile yaptıkları çalıșmalarında mesleki kıdemi fazla olan öğretmenlerin uzaktan eğitim platformlarını daha çok kullanıldığ 1 sonucuna ulaşmışlardır. Katılımcılar öğrencilerin uzaktan eğitimde güvenlik açıklı̆̆ı nedeniyle öğrencilerin istenmedik davranışlar kazanabileceğini belirtmişlerdir. Yine çalışmada öğrencilerde sağlık problemleri oluşturduğu sonucuna ulaşılmıştır. Sağlık problemlerinin başlıcaları ise psikolojik, sosyalleşme ve iletişim bozuklukları olduğu 
görülmüştür. Bozkurt (2020) bu durumları dikkate alarak eğitim kurumlarının hem uzaktan eğitim sürecinde hem de gelecekte yapılacak yüz yüze eğitimde öğrencilerin duyuşsal alanlarına yönelik çalışmalar yapması gerektiğini vurgulamıştır. Attrı (2012) ve Sarı (2020) uzaktan eğitim sürecindeki iletişim poblemlerinin uzaktan eğitimin niteliği artırıldığında yani çevrimiçi ortamda öğrenci öğretmen ilişkisi arttığında kalkacağını belirtilmiştir. Nitekim Karpenko (2008) uzaktan eğitimdeki öğrenci öğretmen iletişimsizliğinden dolayı öğrencilerin ders bitmeden dersleri terk ettiklerini belirtmiştir.

Katılımcılar uzaktan eğitimin öğretmelerin iş yükünü artırdığı görüşündedirler. Öğretmenlerden 1-5 y1l kıdeme sahip olanlar 11-15 yılı k1deme sahip olan öğretmenlere göre olumlu görüş sergilemektedir. Katılımcılar uzaktan eğitimde internet erişimi açısından sıkıntı oluşturulduğuna yönelik görüş sergilemişlerdir. Benzer sonuçlar literatürde mevcuttur (Akgül, 2021; Özdemir Baki ve Çelik, 2021) Ancak mesleki kıdemi 15 yılın üzerinde olan öğretmenler 1-5 y1l olan öğretmenlere göre bu konuda daha olumlu görüș sergilemișlerdir. Bu durumun mesleki kıdemi fazla olan öğretmenlerin il ve ilçe merkezinde görev yapmaları ve internete erişim problemi konusunda daha az sıkıntı yaşadıklarından kaynaklandığı düşünülmektedir. Katılımcılar uzaktan eğitim sürecinin öğrenciler ve öğretmenler üzerinde sağlık problemleri oluşturduğu görüşündedirler. Öğretmenler özellikle fiziksel sağlık problemlerinin yaşandığını belirtseler de psikolojik ve sosyolojik boyutuna dikkat çekmişlerdir. Benzer şekilde uzaktan eğitimin öğrencilerde iletişim, dikkat dağınıklığı ve ilgi dağınıklı problemlei oluşturuduğu sonuçlarınaa ulaşan çalışmalar bulunmaktadır (Altıntaş Yüksel, 2021; Sarı ve Nayır, 2020). Katılımcılar öğrencilerin sosyalleşmesini büyük oranda engellediğini belirtmişlerdir. Bu bakımdan öğrencilerin psikolojik ve sosyolojik açıdan sürekli değerlendirilmesi ve bu konularda çocuklara destek verilmesi gerektiğini belirtilmiştir (Bozkurt ve Sharma, 2020). Katılımcılar uzaktan eğitimde yapılan sınavların ölçme değerlendirme açısından güvenirliğinin düşük olduğunu belirtmişlerdir. Özdoğan ve Berkant (2020) çalışmalarında uzaktan eğitimde ölçme değerlendirme eksikliğini uzaktan eğitimin dezavantaji olduğunu belirtmişlerdir. Nitekim MEB'in uzaktan eğitim sürecinde sınavları yüz yüze gerçekleștirmesi uzaktan eğitim sürecinde bu eksikliğin ortadan kaldırılmasına yönelik olduğu düşünülmektedir.

\section{1. Öneriler}

Uzaktan eğitile ilgili öğretmenlerin görüşlerinin alındığı çalışmanın sonuçlarına göre şu öneriler geliştirilmiştir: MEB'in öğrencilerin uzaktan eğitim yapabilmeleri için gerekli materyalleri (bilgisayar, tablet vb.) sağlaması önerilmektedir. Kırsal kesimlerde yaşanan altyapı sorunlarına çözüm yolları bulunması önerilmektedir. Uzaktan eğitimle ilgili mesleki kıdemi az olan (1-5 yıl) öğretmenlere hizmet içi seminerler vermesi önerilmektedir. Öğrencilerin uzaktan eğitimde dijital araçların başında durmasından oluşacak sağlık problemlerinin önlenmesi için ders saati sürelerinin kısa ve derslerin aralıklı olması önerilmektedir.

\section{KAYNAKÇA}

Adıgüzel, A. (2020) Salgın sürecinde uzaktan eğitim ve öğrenci başarısını değerlendirmeye ilişkin öğretmen görüşleri. Milli Eğitim Dergisi, 49(1), 253-271.

Akgül, G. (2021). Sosyal bilgiler öğretmenlerinin, ortaokul ögrencilerinin ve öğrenci velilerinin pandemi sürecindeki uzaktan eğitime iliş̧kin görüşleri. (Yüksek Lisans Tezi). Uşak Üniversitesi, Lisansüstü Eğitim Enstitüsü, Uşak

Almuraqab, N. A. S. (2020) Shall universities at the uae continue distance learning after the COVID-19 pandemic? revealing students' perspective. International Journal of Advanced Research in Engineering and Technology (IJARET), 11(5), 226-233. 
Altıntaş Yüksel, E. (2021). Sınıf öğretmenlerinin Covid-19 salgını sürecinde çevrim içi dersuzaktan eğitim deneyimlerinin incelenmesi. Ulakbilge, 57, 291-303.

Andoh, R. P. K., Appiah, R., \& Agyei, P. M. (2020). Postgraduate distance education in University of Cape Coast, Ghana: Students' perspectives. International Review of Research in Open and Distributed Learning, 21(2), 118-135.

Attri, A. K. (2012). Distance education: problems and solutions. International Journal of Behavioral Social and Movement Sciences, 1(4), 42-58.

Baki, A., Karal, H., Çebi, A., Şılbır, L. ve Pekşen, M. (2009). Uzaktan eğitimde öğretim yönetim sistemi ve senkron eğitim platformu tasarım süreci: KTÜ örneği. Turkish Journal of Computer and Mathematics Education, 1(1), 87-101.

Bakioğlu, B. ve Çevik, M. (2020). COVID-19 pandemisi sürecinde fen bilimleri öğretmenlerinin uzaktan eğitime ilişkin görüşleri. Electronic Turkish Studies, 15(4).109129.

Bayrak, M., Aydemir, M. ve Karaman, S. (2017). Uzaktan eğitim öğrencilerinin öğrenme stilleri ve doyum düzeylerinin incelenmesi. Çukurova Üniversitesi Eğitim Fakültesi Dergisi, https://doi.org/10.14812/cuefd.310022.

Bozkurt, A. (2020). Koronavirüs (Covid-19) pandemisi sırasında ilköğretim öğrencilerinin uzaktan eğitime yönelik imge ve algılarn: bir metafor analizi. Uşak Üniversitesi Ë̆itim Araştırmaları Dergisi, 6(2), 1- 23.

Bozkurt, A., Akgun Ozbek, E., Onrat Yilmazer, S., Erdogdu, E., Ucar, H., Guler, E., Sezgin, S., Karadeniz, A., Sen, N., Goksel Canbek, N., Dincer, G. D., Ari, S.,\& Aydin, C. H. (2015). Trends in distance education research: A content analysis of journals 2009-2013. International Review of Research in Open and Distributed Learning, 16(1),330-363.

Burke, J.,\& Dempsey, M. (2020). COVID-19 Practice in primaryschools in Ireland report. National University of Ireland Maynooth, Ireland.

Cabı, E. ve Ersoy, H. (2017). Yükseköğretimde uzaktan eğitim uygulamalarının incelenmesi: Türkiye örneği. Yüksekögretim ve Bilim Dergisi, 7(3), 419-429.

Creswell, J. U., ve Clark, V. L. P. (2014). Karma yöntem araştırmaları: Tasarımı ve yürütülmesi. Ankara: Anı Yayıncılık.

Demir, F., ve Özdaş, F. (2020). COVID-19 sürecindeki uzaktan eğitime ilişkin öğretmen görüşlerinin incelenmesi. Milli Eğitim Dergisi, 49(1), 273-292.

Durak, G., Çankaya, S., Yunkul, E., Urfa, M., Toprakliklioğlu, K., Arda, Y., ve İnam, N. (2017). Trends in distance education: A content analysis of master's thesis. TOJET: The Turkish Online Journal of Educational Technology, 16(1).

Garrison, D. R. (1993). Quality and access in distance education: theoretical considerations. Keegan D. (Ed.), Theoretical principles of distance education, 8-19 London: Routledge.

Gökçe, T. A. (2008). Küreselleşme Sürecinde Uzaktan Eğitim. Ziya Gökalp Eğitim Fakültesi Dergisi, 11, 1-12.

Horzum, M. B., Özkaya, M., Demirci, M., ve Alpaslan, M. (2013). Türkçe uzaktan eğitim araştırmalarının incelenmesi. İönü Üniversitesi Eğitim Fakültesi Dergisi, 14(2), 123140 .

Kan, A, Fidan, E. (2016). Türk dili dersinin uzaktan eğitimle yürütülmesine ilişkin öğrenci alg1lar1. Turkish Journal of Educational Studies, 3(2) , 23-45 . 
Karacaoğlu, M., Karakuş, N., Esendemir, N., ve Ucuzsatar, N. (2021) Uzaktan eğitim üzerine bir araştırma: "Türkçe Öğretmenleriyle Mülakatlar". International Journal of Language Academy, 9(1). 124-144.

Keegan, D. (1986). Interaction and communication. The foundations of distance education. 89107. Kent, UK: Croom Helm.

Keskin, M, ve Özer Kaya, D. (2020). COVID-19 sürecinde öğrencilerin web tabanlı uzaktan eğitime yönelik geri bildirimlerinin değerlendirilmesi. İzmir Kâtip Çelebi Üniversitesi Sağlık Bilimleri Fakültesi Dergisi, 5(2), 59-67.

Kışla, T., (2005). Üniversite ögrencilerinin uzaktan eğitime yönelik tutumları. (Yüksek Lisans Tezi). Ege Üniversitesi Sosyal Bilimler Enstitüsü.

Karpenko, M. P. (2008). The emergence and development of distance education. Russian Education and Society. 50 (3), 45-56.

Kurnaz, A., Kaynar, H., Barışık, C. Ş., ve Doğrukök, B. (2020). Öğretmenlerin uzaktan eğitime ilişkin görüşleri. Milli Eğitim Dergisi, 49(1), 293-322.

Kurnaz, E., ve Serçemeli, M. (2020). COVID-19 pandemi döneminde akademisyenlerin uzaktan eğitim ve uzaktan muhasebe eğitimine yönelik bakış açıları üzerine bir araştırma. Uluslararast Sosyal Bilimler Akademi Dergisi, 3, 262-288.

Moore, M. G. (1989). Three types of interaction. American Journal of Distance Education, 3(2), $1-7$.

Özcan, E., Tosun, N., ve Eken, D. T. (2020). COVID-19 salgını ile acil ve zorunlu uzaktan eğitime geçiş: genel bir değerlendirme. Milli Eğitim Dergisi, 49(1), 113-128.

Özdemir Baki, G. ve Çelik, E. (2021). Ortaokul matematik öğretmenlerinin uzaktan eğitimde matematik öğretim deneyimleri. Batı Anadolu Eğitim Bilimleri Dergisi, 12(1), 293-320.

Özdoğan, A. Ç., ve Berkant, H. G. (2020) COVID-19 pandemi dönemindeki uzaktan eğitime ilişkin paydaş görüşlerinin incelenmesi. Milli Eğitim Dergisi, 49(1), 13-43.

Özmen, Z. (2010). Bir lisansüstü öğrencisinin telekonferans ve uzaktan eğitim uygulamaları dersindeki deneyimleri. Türk Bilgisayar ve Matematik Eğitimi Dergisi, 1(2).

Ramos-Morcillo, A. J., Leal Costa, C., Moral García, J. E., \& Ruzafa Martínez, M. (2020). Experiences of nursing students during the abrupt change from face-to-face to e-learning education during the first month of confinement due to COVID-19 in Spain. International journal of environmental research and public health, 17(15), 5519.

Salar, H.C. (2009). Trends in distance education in Turkey. In the Proceedings of The 23rd ICDE world Conference on Open and Distance Learning Including the 2009 EADTU Annual Conference. Retrieved From: http://UUU.ou.nl/Docs/Campagnes/ICDE2009/ Papers/Final_paper_348salar.pdf

Sarı, H. (2020). Evde kal döneminde uzaktan eğitim: Ölçme ve değerlendirmeyi neden karantinaya almamalıyı? Uluslararası Eğitim Araştırmacıları Dergisi, 3(1), 121-128.

Sar1, T., \& Nayır, F. (2020). Challenges in distance education during the (Covid-19) pandemic period. Qualitative Research in Education, 9(3), 328-360.

Tican, C. ve Gökoğlu, S. D. T. (2021). Ortaokul matematik öğretmenlerinin uzaktan eğitim matematik dersine ilişkin görüşleri. Muğla Sitkı Koçman Üniversitesi Eğitim Fakültesi Dergisi, 8(2), 767-786.

Türker, A., ve Dündar, E. (2020). COVID-19 pandemi sürecinde Eğitim Bilişim Ağ (EBA) üzerinden yürütülen uzaktan eğitimlerle ilgili lise öğretmenlerinin görüşleri. Milli Eğitim Dergisi, 49(1), 323-342. 
Utomo, M. N. Y., Sudaryanto, M. \& Saddhono, K. (2020). Tools and strategy for distance learning to respond COVID-19 pandemic in Indonesia. Ingénierie des Systèmes d'Information, 25(3), 383-390.

Uşun, S. (2006). Uzaktan eğitim. Ankara: Nobel Yayıncılık.

Valentıne, D. (2002). Distance learning: promises, problems, and possibilities. Online Journal of Distance Learning Administration, 5(3).

Yenal, Ç. (2009). Uzaktan Ĕ̈itim. (Yüksek Lisans Tezi). Yeditepe Üniversitesi, İstanbul.

Yıldırım, A. ve Şimşek, H. (2018). Sosyal bilimlerde nitel araştırma yöntemleri. Ankara: Seçkin Yayincilık.

Yılmaz, E., Güner, B., Mutlu, H., ve Arın Yılmaz, D. (2020). Farklı öğrenim kademelerindeki öğrencilere verilen uzaktan eğitim hizmetinin veli görüşlerine göre değerlendirilmesi. Milli Ĕ̆itim Dergisi, 49(1), 477-503.

Yolcu, H. (2020). Koronavirüs (COVID-19) pandemi sürecinde sınıf öğretmeni adaylarının uzaktan eğitim deneyimleri. Açıkögrretim Uygulamaları ve Araşstırmaları Dergisi, 6(4), 237-250.

\section{EX̄TENDED ABSTRACT}

\section{Introduction}

While studies on distance learning are discussed at the university grade, its scope and function are discussed according to each education grade after the COVID-19 pandemic. In fact, the Ministry of National Education (MoNE) and Higher Education Council (HEC) announced that the education process will continue with distance education in all classes due to the pandemic. The Ministry of National Education later said that even if face-to-face education starts after the pandemic process, distance education will continue. Considering these situations, distance education has now become an important part of the education process. Therefore, the aim of the study is to reveal the opinions and expectations of teachers about distance education in an objective way. It is important for the measures to be taken to reveal the positive and negative effects of students and teachers, who are the partners of distance education, which became widespread in the education process after the COVID-19 pandemic. In this regard, revealing the opinions of teachers, who are the most important partner regarding distance education, reveals the importance of the research. It is accepted that the teachers who said their opinions within the scope of the research answered voluntarily and sincerely.

\section{Methods}

Convergent parallel design, which is a mixed method research model, was used in the research. In the convergent parallel design, the quantitative and qualitative stages of the research process are applied simultaneously. In this design, while analyzed data, quantitative and qualitative data are analyzed separately. The results obtained are combined while interpreting. The members in quantitative part of the research participant group consists of teachers working in Konya. For this purpose, a questionnaire was conducted to the teachers working in the schools in Konya city center and provincial districts through easily accessible case sampling. The qualitative participant group of the research consists of 8 teachers using the maximum variation sampling method. Two types of data collection tools were used simultaneously in the study. The opinion questionnaire on Distance Education constitutes the quantitative data collection tool of the research, and the semi-structured interview form constitutes the qualitative data collection tool of the research. The quantitative and qualitative data of the study were collected in the second semester of the 2020-2021 academic year. The questionnaire of teachers' opinions related to distance education was conducted to the 
participants by the researchers. The interviews with the participants were carried out face to face. In the analysis of the data related to the first sub-problem of the research, it was decided by looking at the average of the teachers' opinions. In the other quantitative sub-problems of the study, difference analyzes were performed for each matter. Mann Whitney U and Kruskal Wallis tests, which are nonparametric tests, were used in the difference analysis and the level of significance was taken as .05. In the qualitative part of the research, interviews were conducted deeply with the teachers about distance education in order to increase the credibility of the study and their opinions were confirmed. The transmissibility of the qualitative part of the study was ensured by participant diversity and detailed description.

\section{Results}

The participants responded as "Strongly Agree" to the view that students' learning difficulties can be solved more easily with distance education than with face-to-face education. The participants responded as " Not Agree" to the view that distance education provides equal opportunity in education. Participants responded as " Partially Agree" with the view that information is easily accessible through distance education. Participants answered " Agree" to the view that distance education platforms (Zoom, Teamlink, etc.) can be used easily. Participants responsed as " Definitely Agree" to the view that distance education can cause health problems due to long stays in front of the computer. A statistically significant difference was found between men and women in favor of men in the opinions of the participants about the easy management of distance education from a single point with mobile compatibility. A statistically significant difference was found according to the variable of professional seniority in the opinion of the participants that distance education platforms (Zoom, Teamlink, etc.) can be used easily. According to the mean ranks, there was a positive significant difference between the opinions of the teachers in the seniority group of 15 and above compared to the opinions of the teachers in the 1-5 seniority group. A statistically significant difference was found according to the professional seniority variable in the opinions of the participants that students should receive educating in order to use distance education platforms (Zoom, Teamlink, etc.) According to the mean ranks, the opinions of the teachers working in the village/neighborhood were found to be positive significantly different from the opinions of the teachers working in the province.

\section{Discussion and Conclusion}

In the study, the participants reacted negatively to the view that distance education facilitates the solution of learning difficulties. As a reason, the teachers presented that distance education cannot be applied in every field and grade. Similar to this situation, there are also results indicating that practice courses are not learnt properly in distance education. In fact, it is stated that there should be effective communication in classroom management in order to solve learning difficulties in distance education, and it has been realised that communication between teacher and student is among the disadvantages of distance education. The reason for the partial support of the participants that information can be accessed faster through distance education shows that teachers and students can meet at any time in different places. As a matter of fact, this reason is also included in the definition of distance education. Participants also answered "Partially Agree" to the opportunity to receive education without the need for a school environment. The disadvantageous part of this situation is that the students are lack of socialization and peer education. Its advantageous is that students do not fall behind in lessons and everybody has independent of time. It is also able to watch distance education course videos over and over again. According to the results of the study, in which the opinions of the teachers about distance education were taken, the following suggestions were developed: It is recommended that the Ministry of National Education provide the necessary materials (computer, tablet, etc.). It is recommended to give in-service seminars to teachers with a low professional seniority (1-5 years) related to distance education. It is recommended that MoNE develop a valid and reliable system of assessment and evaluation for distance education. 